\title{
The Role of Financial Institutions in Smallholder Agriculture Development:Ethiopian Context
}

\author{
Meseret Meskele Guja \\ Department of Rural Development and Agricultural Extension, Wolaita Sodo University
}

\begin{abstract}
Financial constraints in smallholder agriculture remain pervasive in developing countries like Ethiopia. The government of Ethiopia is doing its best to tackle the financial bottleneck through financial inclusion and several institutional arrangements that hinder smallholders' agriculture that represent the landslide figure in the country. This review is aimed at finding financial institutions serving smallholders in the country, evaluating the mode of service delivery of financial institutions regarding smallholder development, exploring the challenges of financial institutions, and examining the challenges that hinder smallholders in accessing services from financial institutions. There are formal, semi-formal, and informal institutions are delivering service packages to alleviate the smallholders' financial problems through credit, saving, insurance, and to some extent, insurance services. In terms of terms, formal financial institutions (banks and insurance companies) have virtually no access to the rural population; they are all located in urban and semi-urban towns, classify smallholder agriculture as a risky business, discriminate against smallholders, and require collateral that smallholders cannot provide. However, they reach smallholders indirectly through loans they provide to the MFIs. MFIs and RuSACCOs are the main formal and semi-formal institutions that are mainly established on a poverty lending approach. Startup capital supply for SMEs is attached to MFIs indifferently. They are serving smallholders through loan provision and saving and have devised a group lending scheme where members will be accountable for others. Despite the financial inclusion proclamation, MFIs are dominated by the ruling political party. However, they are the most profound financial institutions that serve smallholders and the poorest segment of the population. Despite the tremendous expansion, progress, and the enormous resources mobilized by financial institutions in the country, especially MFIs and RuSACCOs, a substantial proportion of the rural population remains underserved. Due to the one-size-fits-all services of MFIs and the limitation of funds to expand clients, extremely low uptake and sluggish penetration of the credit service to smallholders indicates the prevalence of unbanked and untapped financial potential. Therefore, 80 percent of the poor and smallholders depend on the informal financial sector, mainly on Iqqub, Iddir, and money lenders, since they are culture-appropriate, flexible, easily accessible, and cost-effective. Insurance endeavors are rarely known in Ethiopian smallholders' context despite its necessity. Thus, strengthening the capacities of MFIs and RuSACCOs, linking need-based input credit, designing a credit guarantee scheme, connecting these institutions with other government payment schemes, meeting the credit demands of commercial, semicommercial, and subsistence smallholders, and launching and scaling up WII on a micro-insurance platform are all essential.
\end{abstract}

Keywords: Financial institutions, formal, informal, semi-formal, smallholder agriculture

DOI: $10.7176 / \mathrm{EJBM} / 14-1-03$

Publication date: January $31^{\text {st }} 2022$

\section{INTRODUCTION}

\subsection{Background of the Review}

With more than 112 million people, Ethiopia is the second most populous nation in SSA next to Nigeria and alarmingly increasing at 2.9 percent per annum. Ethiopia is one of the fastest growing economies in the region and, however, it is also one of the poorest countries in the World, with a per capita income of $\$ 850$ (World Bank Group, 2020).

Among the 21 FAO-relevant SDG indicators, two are associated with target 2.3. This target envisages, in particular, doubling, by 2030, "the agricultural productivity and incomes of small-scale food producers, in particular women, indigenous people, family farmers, pastoralists and fishers, including through secure and equal access to land, other productive resources, and inputs, knowledge, financial services, markets and opportunities for value addition and non-farm employment."

Despite the Ethiopian economy being broad-based, the agriculture sector is one of the important segments that have mostly been considered as a backbone for the economy. According to the report obtained from the NBE (NBE, 2020), out of the 6.1\% GDP growth of the country in 2020, agriculture's share was about $35.45 \%$ indicates that it is still continued as the backbone of the countries' economy. The sector employs roughly $85 \%$ of the labour force and generates $90 \%$ percent of export (foreign currency) earnings (Doreen and Philip, 2014). Smallholder farming is the dominant division of Ethiopian agriculture and remained an important integral part to achieve food security since they cultivate about $95 \%$ of the cropped land and produce above $90 \%$ of the agricultural output thereby tremendously contributing to the national GDP increment. 
In several developing countries, including Ethiopia, the financial sector plays a paramount role in the development of agricultural sectors through facilitating the application of productivity-improving modern technologies by the farming communities and enterprising the vast rural poor as a means of raising smallholder incomes and eliminating poverty and rural deprivation.

Tackling poverty in Ethiopia requires a fundamental transformation of smallholder agricultural production to modernized ones through the application of improved technologies. Therefore, well-functioning financial institutions have a paramount importance in smallholder agriculture development and for the transformation of rural economies. This demands the provision of finance in solving the shortage of finance that has been hindering the utilization of modern technologies that can improve productivity. The provision of credit services to the poor has been considered as one of the strategies carved to reduce poverty and promote rural entrepreneurship. Increasing access to financial services hold the promise to help reduce poverty and improve development outcomes by enabling the poor to smooth consumption (in cases of adverse shocks such as poor rain, plant diseases, increase food price), start or expand businesses, cope with risk and increase/diversify household income.

Having access to and acquiring financial services by the rural smallholders is one way of improving productivity in the agricultural sector (Irz et al., 2001). Credit has been increasingly accepted as a powerful instrument to lift the rural poor out of abject poverty. It plays a crucial role in increasing agricultural productivity via building up production assets (Amha \& Peck, 2010). It also enables smallholders to invest in land improvements and thereby adopt new agricultural technologies such as high-yielding seeds and fertilizers that increase their efficiency and income (Zeller \& Sharma, 2000). Moreover, microcredit stands to benefit poor individuals who lack collateral, steady employment, verifiable credit history, or other requirements necessary to gain access to formal credit (Bauchet et al., 2011).

In developing countries, however, lack of credit constitutes a critical constraint to the adoption and use of improved inputs and modern technologies of farming (Mpuga, 2010). The poorest families in developing countries have limited access to formal financial services, including credit, savings, and insurance (Bauchet et al., 2011). They, therefore, rely on a variety of informal credits such as local moneylenders, relatives, friends, or merchants. These options are, however, not ideal as they tend to be expensive and unreliable. This is largely because banks and other formal financial service providers, such as insurance companies, traditionally have not considered the poor a viable market and penetration rates for formal financial services in developing countries are extremely low. Apart from the rural poor (smallholders outweighs more), women are the most neglected group from the services of financial institutions. The inability to acquire formal credit support has constrained the capabilities of poor farmers' and women to expand their production and improve their living conditions, technology adoption, nutrition, and health (Bauchet et al., 2011) since the reach of MFIs to the very poor rural poor and women is limited (Beklentİlerİ \& Alemu, 2018) and thus, women tend to rely more on informal credit sources than their male counterparts (Gurmessa \& Ndinda, 2017).

The Ethiopian government enacted the financial inclusion policy to tackle problems of poverty in the rural areas through buffering paucity of finance to boost productivity and achieve transformation of smallholder agriculture by introducing micro-credit institutions which have targeted mostly the provision of credit to the poor households (rural poor farmers) through poverty lending approach. In addition, the government established special financial institutions such as rural saving and credit cooperative organizations. Therefore, the general purpose of this paper is to highlight the role of financial institutions in the development of smallholders in Ethiopia using empirical information. More specifically, identifying financial institutions operating in Ethiopia in serving smallholders' development, how the financial institutions engaged in enhancing the livelihood of the smallholders, and the challenges facing them in light of delivering services for smallholders in the country.

\subsection{Objectives of the Review}

The major objective of the review is aimed at exploring the roles of financial institutions in the smallholders' development in Ethiopia considering through the following sub objectives.

1. To find financial institutions serving smallholders in the country;

2. To evaluate mode of service delivery of financial institutions regarding smallholder development;

3. To explore and the challenges of financial institutions; and

4. To examine the challenges that hinder smallholders in accessing services from financial institutions.

\section{METHODOLOGY}

Electronic literature sources were used to collect relevant information on the 'role of financial institutions in smallholder development' in general and in Ethiopia in particular. Additionally, the information obtained was categorized into three themes as formal, semi-formal, and informal financial institutions' contribution to the wellbeing of smallholders in Ethiopia. Various keywords used to search from the electronic literature include financial institutions, smallholders, formal financial institutions, semi-formal, informal, rural financial markets, Iqqub, Iddir, saving and credit organizations, and financial inclusion. In this review, the relevant findings are 
evidenced from journal articles, books, working papers, thesis and dissertations, reports, and conference discussion papers. Therefore, a total of 105 different sources were reviewed and cited.

The literature searches were conducted on Google search free access book sites Maily through schi-hub (https://sci-hub.se/) and other cites (http://globaltext.terry.uga.edu, http://www.free-management-ebooks.com/, http://booksc.org/, https://www.pdfdrive.com/, www.gutenberg.org, www.manybooks.net, www.free-ebooks.net, www.openlibrary.org, and others). Based on our reviewed literature, the role of formal, semi-formal, and informal institution in the development of Ethiopia's smallholders and their challenges and trade-offs of such institutions were summarized and described.

\section{REVIEW OF LITERATURE}

\subsection{Definitions}

\subsubsection{Who are smallholders?}

There is no universally agreed definition of smallholder farmers. However, numerous papers pointed out common characteristics concerning the biophysical contexts, resource endowments (land and labor), exposure to external opportunities, etc. (Morton, 2007) and (Nagayets, 2005) regarded those who used to cultivate on small plots of land (usually less than 10ha, often less than 2ha), use family labor, and depend on their farms as their main source of both food security and income generation as smallholder farmers. On the other hand, (Salami et al., 2010) considered the number of livestock owned while defining smallholders, besides the above characteristics, as those who own only a few herds of livestock. Furthermore, Dixon et al. (2004) pointed extra issues as smallholders live in areas with high population densities, and the land size range extends up to 10ha or more in semi-sparsely populated arid areas and less than one hectare in favorable areas, in combination with up to ten animals. In addition, smallholders share for their resource constraints such as capital, inputs, and technology, their heavy dependence on household labor, their subsistence-orientation, and their exposure to climate change-induced risks such as reduced yields, crop failure, and low market prices of the produce in common (Diao X., et al., 2010; FAO, 2014). Despite the central position occupied in the debate on agricultural transformation and rural poverty, available definitions of "smallholder" vary significantly, depending on the farm characteristics taken into account, ranging from socio-economic features to resource endowments and agro-ecological dimensions. The term "smallholder" often overlaps and may be used interchangeably with "small-scale agriculture", "family farm", "subsistence farm", "resource-poor farm", "low-income farm", "low-input farm" or "low-technology farm" (Franz Heidues, 2003).

Though the term 'smallholder' refers to their limited resource endowments relative to other farmers in the sector, all the above notions indicate that characteristics of smallholders are not similar across regions, climatic zones, and farming systems. As is mentioned by FAO (2015), the average landholding of Kenyan smallholders was 0.47 hectares and in Ethiopia the average small farm size is 0.9 hectares. Such average landholding was higher for Latin American countries' smallholders and often tends to be over two hectares, as in Nicaragua where the average small farm size is 5 hectares. Besides, smallholders are vulnerable to economic shocks, climatic risks, and deprived of appropriate institutions (access to markets, organization of markets and information, finances, towns, public institutions, and services, etc.) (Dixon, 2004). Therefore, they engage in plenty of livelihood patterns and farming systems to respond against such development impediments.

FAO (2015) noted the similarities of activities of smallholders with entrepreneurs on how they operate their firms. Due to the limitation of resources, smallholders are often seen in making economic decisions on various factors of production. They make decisions and take calculated risks and profits as well. The decisions include what to plant, which inputs to use and how, when to plow, to seed, to harvest; how much to keep for consumption in the household and how much to sell to raise cash, or how much to store. Smallholders diversify their income sources to raise capital to be invested in productive assets and social and human capital through avoiding market and weather risks.

The consequences of any developmental intervention and institutional arrangements on the smallholder farmers have a direct influence on the global social, economic, and environmental scenarios since significant portion of the world's farmland ranges from $62 \%$ in Africa to $85 \%$ in Asia (FAO,2014), were occupied and more than $80 \%$ of the food consumed in the developing world is supplied by smallholder farmers (IFAD, 2013). Moreover, as is indicated by Fanzo (2017), the people of SSA and Asia were getting about $70 \%$ of their kilocalorie requirements from smallholders farmers.

\subsubsection{Characteristics of Ethiopian smallholders}

As it has no clearly stated definition, smallholders constitute a small farm in Ethiopia as is the case in many developing countries. Smallholders account for most of the Ethiopian population and the food grain producers and meet the conventional meaning of small farms as less than two hectares (Mulatu et al., 2020). According to the official landholding data, 61.65 percent of households access less than one hectare, and only 14 percent of households' access above two hectare (Diriba, 2020). From these, 38 percent of households' access less than 0.5 hectares, 23.65 percent access between 0.51 and 1.0 hectares, and 24 percent access between one and two hectare of land indicates the extreme level of land fragmentation and how smallholders are representing the major 
agricultural production and productivity coverage in Ethiopia. Moreover, according to (Diriba, 2020), the practice of mechanized agriculture in Ethiopia is estimated at $0.7 \%$ shows how big the country's smallholder and land fragmentation that could hamper the transformation of the agricultural sector through mechanization and other institutional arrangements. The land fragmentation is severe in the highland where population density is higher. Therefore, Ethiopia is considered the country of smallholder agriculture (Gebreselassie, 2006).

Table 1. Land fragmentation in Ethiopia

\begin{tabular}{ccc}
\hline Number of plots per farm & Number of farmers (\%) & Average farm size per plot (Ha) \\
\hline One plot & 44 & 0.34 \\
Two plots & 23 & 0.37 \\
Three plots & 13 & 0.36 \\
More than 3 & 20 & 0.33 \\
More than 4 & 11 & 0.32 \\
Average number of plots & 50 & 0.5
\end{tabular}
(2.3)

Source: Gebreselassie (2006)

This implies that smallholders are reaching the point where they cannot redistribute their already tiny and fragmented land to the growing labor within their families.

The smaller farm size is complemented by a backward farming system which ultimately results in low productivity (Gebreselassie, 2006) and which is insufficient to feed the rapidly growing population, and thus, the country is dependent on food aid. The low level of households' farm income is a result of both the small size of landholding and the low level of productivity in agriculture (FAO, 2014b). Overall, the low level of productivity is due to various factors such as limited access to credit services, poor infrastructure, (Ogato et al., 2009), and the nature of land tenure systems which do not allow selling or using of land as collateral for loans (Devereux, 2000).

Additionally, Ethiopian smallholders keep few livestock species with diversified herds and characterized by their resource constraints (capital, inputs, and technology), their heavy dependence on household labor, their subsistence orientation, and their exposure to multiple risks (reduced yields, crop failure, and low prices) (Beklentİlerİ \& Alemu, 2018; Tesfay, 2021).

Smallholder farming employs about 12 million farmers (FAO, 2018) and is the main pillar of Ethiopian agriculture and remained an essential segment to achieve food security since they cultivate about $95 \%$ of the cropped land and produce above $90 \%$ of the agricultural output thereby tremendously contributing to the national GDP increment. According to the report obtained from the NBE (NBE, 2020), out of the 6.1\% GDP growth of the country in 2020, agriculture's share was about $35.45 \%$. This indicates that it is still the backbone of the countries' economy.

\subsection{Financial Sector in Ethiopia}

The financial sector in developing countries and particularly the Sub-Saharan African (SSA) region is largely underdeveloped, lacking in-depth, highly inefficient, concentrated in the urban areas, and dominated by a few, often foreign-owned commercial banks. In particular, financial institutions engaged in credit, savings, and insurance markets in the rural areas are generally non-existent, and of those that do, much work imperfectly (Robert Cull, Asli Demirgüç-Kunt, 2006).

The Ethiopian financial institutions evolved through three-stage policies following major economic reforms from financial repression and fostering state-led industrial and agricultural development through preferential credit (in the socialist 'derg' regime) to market-led development through liberalization and deregulation (post 1991 after the fall of the socialist government) and financial inclusion through allowing private banks and MFIs (since second half of 1990s). Prior to the reform process, there had not been any competition within the financial sector due to the fact that all of the formal financial institutions were state-owned, and private financial institutions were not allowed to operate. After the implementation of the reform process starting from 1992, there have been significant measures undertaken by the government (Doreen and Philip, 2014).

The major policy reform measures taken include liberalizing and reforming the financial sector, relaxing foreign exchange controls, dismantling the administered interest rate regime, establishing a new regulatory framework for banks, and insurance companies (Kassa, 2010). The reform has been effective through financial inclusion policy has been effective based on the proclamation 84/1994 that allows the Ethiopian private sector to engage in the banking and insurance businesses and proclamation 40/1996 in 1996 that revitalized and allowed the establishment of MFIs and saving and credit cooperative organizations (SACCOs) that marked the beginning of a new era in Ethiopia's financial sector and opened the opportunity for an inclusive financial sector in Ethiopia (Alemu, 2016).

The formal financial sector has passed a series of legal procedures in terms of proclamation considering some form of modification in order to smoothen the legal sanctions and encourage the establishment of private banks, insurances, and MFIs through proclamation number 270/2002. Based on the performances, achievements, and 
motives of MFIs, a new proclamation was enacted including amendments from the previous ones numbered $626 / 2009$. But the latest proclamation number 1164/2019 devised and started implementation comprising some advanced elements that privileges for MFIs. The most cited amendments incorporated in the latest proclamation are it excludes foreign nationals from the shareholding, granting loans for business activities without compulsory savings, services like agent banking, and provision of interest-free microfinance service. Besides, the new proclamation also stretched to and includes a capital goods finance company, a reinsurer, and a micro-insurance provider. Furthermore, the new proclamation enables MFIs to outsource their critical or important functions including functions related to deposits, loans, and local money transfer.

The existing law prohibits any attempt on the part of microfinance institutions to amend the memorandum of association or article of association without the consent of the NBE. Recognizing the fact that this is too much interference with shareholders' rights and hence, the success of MFIs, under the draft proclamation, the shareholders has full freedom to alter the terms and conditions of the memorandum of association/ article of association. However, they must seek the approval of the National Bank during the registration of the amended version.

Under the new proclamation, the $\mathrm{NBE}$ is empowered to issue directives regarding financial consumer protection, credit-information-sharing, interest-free microfinance businesses, and the minimum condition to provide digital financial service and regulation of advertisement. Therefore, the MFIs are granted the legal right to perform almost all activities that the conventional commercial banks perform. And thus, currently, the ACSI, Omo, and Oromiya MFIs totally shifted their services into banks.

In spite of the significant financial policy reform, substantial gaps continue to persist in the rural financial markets. These gaps relate to the scarce availability of deposit facilities in rural areas, the difficulties that small farmers face in accessing formal agricultural credit, and the paucity of medium and long-term lending facilities. The absence of these financial services has major implications for efforts to modernize the agricultural sector and to increase the incomes of small farms and other rural households.

The financial sector in Ethiopia is broadly categorized into formal, semi-formal, and informal institutions. The formal financial system is a regulated sector that comprises 18 banks (three public banks (The National Bank of Ethiopia (NBE) which is regarded as a central bank of the country, one state-owned development bank, a government-owned commercial bank), 16 private banks), 18 insurance companies (17 private insurance companies, one public insurance company), 41 microfinance (11 public, 13 private, and 17 NGOs) (Ayalew, 2014; NBE, 2020), and saving and credit cooperatives (over 8200 SACCOs) in both rural and urban areas. The saving and credit cooperatives are considered semi-formal financial institutions, which are registered but not regulated and supervised by the National Bank of Ethiopia (NBE). The informal financial sector in the country consists of unregistered traditional institutions such as Iqqub (rotating savings and credit associations), Iddir (death benefit association), and private money lenders (Arata abedari).

One of the encouraging developments in the financial sector towards inclusiveness in Ethiopia is the expansion of MFIs and saving and credit cooperative organizations. By the end of 2019/2020, about 41 MFIs (11 public (regional states), 13 private, and 17 NGOs) are functioning in the country and voraciously opening branches and sub-branches in lower districts, especially rural, of the country (Alemu, 2016; NBE, 2020; Tizazu, 1994). Objectives of the MFIs focus on reducing poverty and vulnerability by increasing agricultural productivity and incomes, diversifying off-farm sources of income, and building household assets (Liverpool \& Winter-nelson, 2010). Despite these attempts by the government to provide credit to the rural poor, still, outreach in Ethiopia is low and has not satisfied the demand of the rural poor (Doreen and Philip, 2014).

They provide saving mobilization, loan provision for different purposes including startup capital for newly established enterprises, and, to some extent, micro-insurance services (World Bank, 2008). Their aggregate capital and asset reached Birr 19.4 billion and Birr 92.2 billion, respectively. At the same time, they mobilize a deposit amount of Birr 44.7 billion while their outstanding credit is Birr 64.9 billion. The MFI sector is dominated by the five largest MFIs consisting of Amhara, Dedebit, Oromiya, Omo, and Addis credit and savings institutions, which accounted for 82.6 percent of the total capital, 90.1 percent of the savings, 85.9 percent of the credit and 86.3 percent of the total assets of MFIs by the end of 2019/20 (Gelaw, 2019; NBE, 2020).

\subsection{Financial Inclusion and Why It Matters?}

Financial inclusion has been broadly recognized as critical in reducing poverty and achieving inclusive economic growth. Financial inclusion is not an end in itself, but a means to an end. There is growing evidence that it has substantial benefits for the poor, a disadvantaged and neglected segment of the population, and smallholder farmers. Studies show that when people participate in the financial system, they are better able to start and expand businesses, invest in education, manage risk, boost productivity, and absorb financial shocks (Bruhn \& Love, 2014; Dupas \& Robinson, 2013).

Financial inclusion encompasses the creation of opportunities for poor people to benefit from financial resources from the financial institutions through the opening of banking accounts. But it doesn't stop there only 
with regular use, people fully benefit from having an account. Both these outcomes can be difficult to achieve. Digitizing payments can play an important part. Shifting payments such as wages or government transfers from cash into accounts can increase the number of adults with an account. Digitizing payments such as those for school fees or utility bills allows people who already have an account to benefit more fully from financial inclusion by enabling them to make the payments in a way that is easier, more affordable, and more secure (Demirguc-Kunt et al., 2015).

Access to accounts and savings and payment mechanisms increases savings, empowers women, and boosts productive investment and consumption. Access to credit also has positive effects on consumption as well as on employment status and income and on some aspects of mental health and outlook (Karlan \& Zinman, 2010). The benefits go beyond individuals. Greater access to financial services for both individuals and firms may help reduce income inequality and accelerate balanced economic growth (Klapper et al., 2006; Robert Cull, Asli DemirgüçKunt, 2006).

Informed by a fast-growing body of knowledge and experience, policymakers and regulators are beginning to make expanding financial inclusion a priority in financial sector development. An increasing number of national governments are introducing comprehensive measures to improve access to and use of financial services (Demirguc-Kunt et al., 2015).

\subsection{Financial Inclusion in Ethiopia}

Despite strong efforts by banks to offer formal financial products to attract clients and offer new financial services, financial inclusion in Ethiopia has a long way to go, as the country was ranked the last second in terms of financial inclusion among 26 politically, geographically, and economically identical countries. In 2014 , only $7.4 \%$ of adults in sub-Saharan African countries used formal credit at the financial institution, while $18 \%$ used it in high-income economies, and mobile banking in Africa is at a leading position (Demirguc-Kunt et al., 2015).

Many developing countries have acknowledged using financial inclusion strategies since 2010 (Baza \& Rao, 2017). According to the World Bank (2015) database, 1.2 billion adults have opened accounts since 2011, while 515 million of them have opened accounts since 2014. From 2014 to 2017, adults who accessed accounts using a mobile banking service globally rose from $62 \%$ to $69 \%$. In developing economies, the number rose from $54 \%$ to $63 \%$. However, in developing economies, the percentage of women remains 9\%. In sub-Saharan Africa, women are not encouraged to do business due to cultural barriers, but mobile banking services drove financial inclusion in countries of sub-Saharan Africa (Demirguc-Kunt et al., 2015).

Ethiopia is, however, lagging behind its neighbors. For instance, $82 \%$ of adults own accounts in Kenya, 50\% in Rwanda, and $43 \%$ of adults have an account in the region. Only less than one-quarter of adults in Ethiopia have a formal account. Some private and public bankers could argue that ownership of formal accounts is increasing (Adeola \& Evans, 2017).

The main reason why financial institutions in Ethiopia do not have a bank account is the lack of funds and the fact that financial institutions are too far away, while religious reasons and lack of trust in financial institutions are the least. (Beck et al., 2015) note that African banking systems are less inclusive than non-African ones. $16.5 \%$ of households in a medium-sized African country report having an account with a financial institution. Only $10 \%$ of households in Ethiopia have access to formal credit, of which only $1 \%$ of the rural population has a bank account. Based on the findings the main reason that more than $85 \%$ of adults $(15+)$ in Ethiopia do not have a bank account or any other financial institutions is an insufficient fund, and the other reason that hinders access to a bank account is that financial institutions are too far away from them. However, religious reasons and lack of trust in formal financial institutions are the least (Lakew \& Azadi, 2020).

The financial inclusion policy of Ethiopia triggered the establishment of MFIs, RuSACCOs, and the formal banks, particularly the CBE and DBE, though devising a system of credit access for the industrialization process in general and the rural industrialization process in particular. Such financial institutions play a crucial role in the development of rural areas through building rural industries. The rural industries obtain the raw materials from the localities, labor from rural areas, and products and services will be consumed by the rural people with, comparatively, cheaper prices. Smallholders can be hired and obtain additional income to buffer the financial needs that could not be filled alone with their agricultural income. This approach resembles the China's path of rural industrialization. However, despite the region-specific MFIs approach resembling China's path, the service delivery is far from being compared with China's rural industrialization (Durie, 2018). For this purpose, GoE gave and additional preferential advantage in the form of duty-free and land availability to further promote the rural industrialization process that can possibly facilitate the rural transformation.

Following the global movement, rural financial markets (RFMs) in Ethiopia have received substantial policy attention in recent years, which has led MFIs and member-based RuSACCOs to flourish. In the last few decades, Ethiopia's rural financial markets have grown unprecedently and the outreach of rural cooperatives to rural households is expanding over time (Amha \& Peck, 2010). The startup of MFIs and RuSACCOs is considered a powerful lever to provide credits and deposits possibilities to poor individuals who are largely ignored by 
commercial banks and other lending institutions. The reasons of this neglect are many. Often, such credits are just not profitable enough for banks, because of economies of scale. By focusing on small amounts and easing collateral requirements, MFIs are better equipped to target poor individuals or groups who need resources to finance small scale investments (Ferro-Luzzi \& Weber, 2011).

Sustained access to rural financial markets remains crucial to income-enhancing opportunities and hence to the improvement of rural livelihoods in developing countries where Ethiopia is not an exception. Access to finance has a multiplier effect and plays a transformative role in smallholder agriculture. Therefore, the transformative role has generated renewed interest in the development of rural financial markets in terms of financial inclusion approach which has become known as the 'microfinance revolution' in the last four decades.

The long-list of hopes that rural finance is thought to deliver are conceptually well-founded and intuitive that small loans can, among other things, transform the smallholders' and poor's' economic activities, increase incomes, and enable their children to go to school. These arguments find their origins in the common assumption that the marginal return to capital is larger when capital is scarce, and by implication, finance should flow from richer areas to poorer areas, enabling the poor to reap sizeable returns from access to finance (Conning \& Udry, 2007; Karlan \& Morduch, 2010). The focus on access to credit has, over time, moved to embrace the provision of broad-based financial services (such as credit, savings, and insurance) to all, rather than just delivering credit to small businesses (Karlan \& Morduch, 2010). Given the importance placed on the transformative power of access to broader financial services, MFIs have flourished across the developing world, including in Ethiopia, in the last few decades (Abay \& Berhane, 2019).

\section{RESULTS AND DISCUSSIONS}

\subsection{Nexus between Financial Institutions and Smallholders in Ethiopia}

The government of Ethiopia gave due concern to have financial inclusion and performed various activities that enhance and strengthen it. The enactment of proclamation no 40/1996 marked the beginning and since then huge success has been recorded. Reports indicate that the expansion of public and private banks and insurance companies as well as other semi-formal financial institutions like saving and credit cooperatives is tremendous. The loan disbursement was substantially increased and induced information technologies into their inclusion agenda, especially the mobile banking service (which is aligned with the reform processes of telecommunication services) into their systems (Alemu, 2016; IMF, 2020). The total capital and net worth of banks and insurances were increased dramatically as well. However, as they are criticized, their practices were limited to the mobilization of savings and delivery of loans for state-owned entities. According to the IMF (2013) report, over $70 \%$ of loans have been going to the state and state-owned enterprises while less than $30 \%$ of the finance has been going to the private sector.

As it is mentioned above, the microfinance sector is dominated and monopolized by the ruling political party that needs to be liberated to further enhance their capacity in reaching smallholders. The input distribution strategy that strongly ties with such state-owned MFIs limited the space for not only private MFIs but also limited the space available for the emergence of private sector input retailors. Thus, those farmers with sufficient resources to purchase fertilizer for cash, often on more favorable terms than on credit, are unable to do so since there are very few private traders (Derek et al., 2007).

Despite the tremendous expansion, progress, and the enormous resources mobilized by financial institutions in the country, especially MFIs and RuSACCOs are concerned, studies indicate that a substantial proportion of the rural population remains underserved yet (Amha \& Peck, 2010). These institutions are meant to mobilize saving, provide loans, and to some extent, micro-insurances and however their extremely lower uptake and sluggish penetration of the credit service to the smallholders (Alemu, 2016) makes paradox and indicates that the prevalence of unbanked and untapped potential (Bernard \& Spielman, 2008). Against the estimated huge potential unmet demand (80 percent according to Wiedmaier-Pfister et al. 2008, for example) and the relatively substantial expansion of rural financial institutions in the form of CBE branches, MFIs, and RuSACCOs in recent years, the fact that only a small proportion of households take up loans remains a paradox again. However, evidence indicated that MFIs are, comparatively, better suited than any other formal financial institutions in an expanded manner in reaching the smallholders in providing finance as a buffer during extreme need to invest in their agriculture and arise a rural enterprise in their locality.

Despite, the current three years plan (Homegrown Economic Reform Program) encompasses the aim of developing the financial sector to support credit to the private sector as an essential segment to reach the smallholder farmers in assisting them to boost productivity, it is not enough and requires improvement of capacities of private MFIs through appropriate policy instrument that encourages them to engage in smallholders' development endeavors through designing strategies that fit nature of smallholders through compromising profit and social targets.

\subsubsection{Positive Outcomes}

The contribution of financial institutions to the national economy of different countries in general and the 
livelihoods of smallholders, in particular, have been reported by multiple scholars. Access to finance to the agricultural communities in Vietnam improved the decision-making pattern of smallholders in adopting technologies and investments (Barslund \& Tarp, 2008), and access to institutionalized credit has found the households' monthly revenue in Pakistan (Abedullah, N. Mahmood, 2009; Iqbal et al., 2003). On the reverse angle, financial constraints were commonly found in hindering farm productivity, profit, and livelihoods of smallholders. When compared, farm profit is reduced by 27 percent for those who are constrained by finance than their accessed counterparts in Peru (Diana et al., 2010). Similarly, as it is found by Mafi et al. (2010), financial paucity is a major cause for the persistent poor performance of the agricultural sector in Nigeria and lower welfare outcomes in the Democratic Republic of Congo (Muayila, 2012).

Financial scarcity plays a paramount role in hindering the productivity, wellbeing, and development of smallholders in SSA in general and Ethiopia in particular. The main solution proposed and implemented to overcome the paucity of finance in rural areas to develop smallholders in Ethiopia is well-thought-out as the provision of loans, savings, and other financial services. The ideal, as considered by the government, is the establishment of MFIs that can possibly be pragmatic within the country's rural dynamics. It is taken as a perfect tool to reduce poverty in rural areas than other development programs. Despite numerous government as well as non-governmental efforts to reduce the poverty of rural marginalized people through microfinance over the last decade, poverty remains deeper, and yet much remains to be done to improve the quality of life of poor people. Perhaps no other development strategy has attracted so much global attention in the history of poverty-focused development than micro-finance (Daniel, 2014).

Though the financial sector is not yet developed and limited in its outreach strategies, their aggregate role in improving the wellbeing of borrowers is found positive in Ethiopia. Geremewe, (2019) revealed the positive contribution of MFIs in the country to the increment of household income, better education, living conditions, and access to basic needs. Besides, utilization of credit from MFIs has been found in improving the consumption and asset growth as well as utilization of improved agricultural technologies like seeds, fertilizers, and others (Liverpool \& Winter-nelson, 2010). Moreover, microfinance programs have improved the savings of the respondents by letting them access saving services and increasing household income out of which they can use to save. After joining microfinance programs, the mean monthly expenditure of the respondents has significantly increased in food, clothing, housing furniture, health, education, and service items (Afework \& Endrias, 2016; Ebimobowei \& Sophia, 2012).

The improvement in saving habits is mainly due to the nature of the credit scheme which imbedded compulsory saving to obtain credit. As Kereta (2007) presented, mandatory saving played a tremendous role as almost all MFIs enforce it in the beginning to access loans and, at the same time, the clients cannot withdraw all the loans allotted for them rather some amount remains as saving for future use.

The MFIs have been found to play a paramount role in improving the life of smallholders and rural poor in all the regions they perform in. Amogne et al. (2018) revealed in their study in the North Shew Zone, Amhara credit and saving institution's (ACSI) improved the overall living standard of its smallholder clients in the area through micro-financing scheme and the welfare improvement is observed through household consumption (Gadasandula, 2020). Omo MFI is found in reaching the excluded poor in remote areas through group lending schemes and improving the clients' income, productive asset holdings, access to various social services in Wolaita Zone (Daniel, 2014). Besides, 85.5 percent of the smallholders were found to be saveing in the MFIs in Derra District of Oromiya region (Zeleke \& Endris, 2019) due to its advantages over other formal institutions.

\subsubsection{Shortfalls of the financial institutions in serving smallholders in Ethiopia}

Financial constraints in smallholder agriculture remain pervasive, and they are costly and inequitably distributed, severely limiting smallholders' ability to compete. Basu et al. (2004) indicated the Ethiopian case similarity with the contexts of the SSA countries in general in that most of the poor population in rural areas and small enterprises has very limited access to deposit and credit and other financial services provided by financial institutions. The outreach of the financial institutions to smallholders is minimal though whose contribution to the agricultural growth is tremendous. The World Bank (2008) noted that despite the microfinance revolution, providing access to credit without formal collateral, has opened access to loans for millions of poor people, it has not reached most smallholder agricultural activities, except in high-turnover activities such as small livestock and horticulture.

Smallholders are lacking legally proved fixed assets that can be used as collateral to secure loans from formal financial institutions, and therefore, these institutions are reluctant to deliver loans on an individual level due to fear of the possibility of defaults. Therefore, the provision of collateral requirements to obtain credit from formal financial institutions for smallholders is a challenging due to poor resource endowments of the majority, lack of legal entitlements for the assets, and others. In cases when smallholders' resources are converted into monetary values, it requires a huge amount. As it is uncovered by Mekonen and Melesse (2014), 85.4\% of total loans require collateral and the required collateral as percentage of loan is $234 \%$ which is the highest in the SSA.

MFIs designed a strategy to reach smallholders through lending without collateral requirement, i.e. group lending. Group lending uses group responsibility as group collateral making all members jointly responsible for 
the repayment of every group members' loan to minimize default risks (Mulatu et al., 2020). This requires confidence on the member's ability to pay the loan back and the decision to be a member is made by the members rather than the lending institution. Through the group lending scheme, lions share resource-poor smallholders up on them people lack confidence that they can pay the loan back are neglected and excluded from group formation. The group lending scheme further hinders those smallholders who want to get loan alone (Daniel, 2014). Consequently, therefore, they are forced to depend on both the informal-sector and moneylenders where they borrow at skyrocketed interest rates (Muriu, 2011; Obo, 2009). Hence, the informal sector is the dominant sector in that $80 \%$ of the poor depend on informal financial sector (Demirguc-Kunt et al., 2015; Komicha, 2007) suggesting that more can be achieved in terms of increasing the outreach of MFIs.

The clients of MFIs in Ethiopia are characterized by more rural, living on crop farming, most with no large farm animals or only one ox. Besides, the household size was quite higher than the national average, with a high ratio of illiterate individuals. Most lack basic items, such as a bed and table, and chairs and live on a mud floor with poor housing indicates that MFIs in the country are designed to serve smallholders through poverty lending approach where extreme poverty and deprivation persisted for long and the main goal was eradicating poverty rather than profit-making (Obo, 2009).

The clients of MFIs obtain loans based on their wealth status as criteria after conducting wealth ranking and judgments from the local authorities to target poor smallholders. However, it is criticized for the smaller amount of loan that cannot be adequate to invest in profitable businesses like micro-enterprises and obtain the full agricultural input packages during a particular cropping season. As it is quoted in Obo (2009), Wolday (2003) mentioned that the loan size is five times less than the world average and two times less than the SSA. In the study conducted by Geremew and Toli (2016) in Wolaita and Dawro Zones, about 77 percent of SME operators claimed that the loan that is available from the MFIs is not adequate for their planned business start-up. Besides, Gelaw (2019) indicated that with slow growth in the size of the loans per head of the Amhara MFIs that it is difficult to have a meaningful investment with such a small loan.

The credit product provision assumed by the formal financial institutions follows the one-size-fits-all approach including smallholders that cannot tailor their needs and are too costly (Bastin \& Matteucci, 2007). Therefore, a significant proportion of smallholders in Ethiopia still rely on informal finances even if costs are substantially lower in the formal than in the informal sector and both coexist in the same market. The study conducted by Mersha and Ayenew (2018) substantiated the very nature of financial service coverage as the smallholders in the South Western parts of the Oromiya region prefer informal sources for credits due to the fact that MFIs and RuSACCOs' tiresome lending procedures and short and tight repayment schedules (Mcintosh et al., 2013). The short-term nature of credit from the formal institutions is argued as having hampered the long-term investment thereby affecting the transformation of smallholder agriculture (Admassie, 2004). At the same time, Geremewe (2019) suggested weak monitoring and support system, absence of concessional interest rate, uncomfortable loan repayment schedule, lack of use of technology, and cost-effective methods by formal financial institutions as a major shortfall.

Besides, about 65 percent of the households were accessing credits from informal institutions in the Amhara region (Aderaw and Manjit, 2016). Additionally, the survey conducted in four Zones of the Amhara region (Mcintosh et al., 2013) specified that only 20.9 percent of smallholders were clients of MFIs and consequently, 70 percent of those who obtained any loans for agricultural inputs obtained from primary cooperatives, about $15 \%$ from MFIs, and the remainder from family, friends, and others $8 \%$ from private traders and companies (Mcintosh et al., 2013) shows that the limitation of services as well as the lower penetration of all the formal financial institutions to smallholders' development. The overall characteristics of the formal financial institutions and the supply side limitations, of course, impeding the smallholders' access to finance, the smallholders' lesser financial demand from such institutions also contributes to the lower penetration of the services. Moreover, the demand for a loan from formal financial institutions is constrained by various factors and as mentioned (Komicha, 2007) like participation in the non-farm income, more dependent household members and higher interest rate were negatively influencing the credit demand by smallholders from the formal source. The negative perception of farm households in formal credit participation has been attributed to the isolation of very poor farmers from group formation in the case of group lending system. Number of livestock owned, group lending, and distance from the lending institution were factors influencing participation of households in formal credit use negatively as evidenced by the model output (Mamuye, 2021).

Those smallholders who obtained loans from the MFIs are not allowed to claim again even though they approach in group and properly pay their loans since MFIs strictly follow a credit rationing approach. This notion is reinforced by the finding from Komicha (2007) as the credit rationing by the formal financial institutions as one of the factors that push farmers and other small entrepreneurs to switch to informal credit sources. The credit rationing combined with the imperfect financial market and small loan products adversely affect the credit sector choice by smallholders in the country.

Despite its expected critical role in the country's economy, the Ethiopian financial market still remains 
shallow and underdeveloped. Immunization of ICTs into the microfinance services can definitely reduce the transaction costs to obtain loans and minimize the lengthy bureaucratic chains and make the services easily available, especially for smallholder farmers. As World Bank (2008) noted the utilization of agricultural credit cards to purchase inputs or cellular phones to complete banking transactions made loans less costly for smallholders in different countries. However, services of MFIs in Ethiopia are performed manually, which creates the loan service costly and needs to inculcate ICTs in their service delivery endeavors to have better access to credit, saving facilities, money transfer mechanisms, and remote payments by smallholders.

There are also arguments that the monopolistic involvement of the state in the financial sector hindered the overall performance of the financial sector in serving the smallholder majorities. If the financial market is fully liberated, the increased competition among financial sectors, especially the MFIs, may contribute to wellfunctioning markets, protection of consumers, promotion of allocative and technical efficiency, and the provision of incentives to develop new products (Assefa et al., 2013). In a competitive market, costs of operation will decrease, institutions diversify their services, and the efficiency of their operations will be improved through the delivery of quality services to retain clients and attract new ones. Besides, the increased competition in the MFIs results in lower interest rates for borrowers, improved and new financial product designs and better customer services, and better able to cross-subsidize loans to poorer clients in reaching the smallholder majority (Assefa et al., 2013).

\subsection{Formal Financial Institutions in Ethiopia with respect to Smallholder Development 4.2.1. Commercial banks}

The formal banking sector is getting advanced, new banks are emerging, all are improving their service delivery and increasing clients, their working capital and assets are rising with high rates, the financial flow in the country is tremendous, and their capacity in assisting and shouldering the continued economic growth of the country is being improved. However, a significant portion of Ethiopia's population lives without access to basic, affordable, and sustainable financial services (Doreen and Philip, 2014). Besides, in spite of their high excess liquidity and the low yield on safe assets, these institutions are highly criticized for being unable to satisfy the various credit needs of the poor farmers in the country. The possible reason cited in various literature is the perception by commercial banks of the unattractive risk-return outlook of serving the low-income rural population.

Commercial banks prefer high-income clients who borrow large loans. These banks are located in urban areas where, comparatively, improved infrastructural facilities were concentrated. Because of the inability to secure the loan with fixed assets, the smallholders and poor are considered as "high risk" borrowers and credit was only accessible to large commercial farmers and industrial business activities. On the other hand, due to complex bureaucratic procedures, high administrative costs, long-distance, unstable interest rates, and the demand for small loans, rural poor households in Ethiopia are out of the reach of formal financial institutions.

The formal financial institution (commercial banks and insurance companies) are assumed to be uprooted from the Western world and inappropriate to Ethiopian realities and thus, the great bulk of the Ethiopian population, including the majority of urban dwellers, makes little use of the formal financial intermediaries. Their high costs of transactions, elaborated paperwork, high collateral requirements, delays, etc. are among some of the factors that militate against effective utilization of the existing insurance and banking facilities (Aredo, 2017).

This, together with the high demand for bank loans in the mainstream economic sectors of the country, has created a comfort zone for the existing commercial banks, leading Ethiopia to be one of the least banked countries in the world. As is mentioned (Demirguc-Kunt et al., 2015), 22 percent of Ethiopians had banking or saving accounts in either formal or semi-formal institutions in 2014 and which is lower than the SSA average (29 percent). Thus, the limitations of financial institutions in providing the rural poor with credit have become the driving forces behind the emergence of MFIs in Ethiopia (Birchall, 2013).

\subsubsection{Insurance companies}

Weather-indexed insurance (WII) is one of the most common strategies launched by IFAD at global level (IFAD, 2013) that smallholders are insured for various risks. The index can be based on the amount of rainfall (lack or excess), humidity levels, the arrival of locusts, occurrence and strength of a hurricane, frost, hailstones, drought, etc., or price instability, smallholders would be resilient and tend to rapidly invest in productivity-enhancing innovations when insured,. However, despite WII could improve the food security of smallholders through upscaled use of index-based insurance in the context of their socio-economic conditions and institutional arrangements (Isaboke et al., 2016), studies revealed that the uptake of such WII by smallholder farmers is very low. Abate et al. (2016) also exposed the lower level of uptake of WII by smallholders in SSA. Moreover, the study conducted in Kenya indicated that a low level of uptake of WII is attributed to various aspects by smallholders (Sibiko et al., 2018).

Effective implementation of WII requires highly capable and independent measurement tools, such as weather stations. Remote-sensing techniques with satellites are being used as well (e.g., Canada, USA). In some insurance systems, an estimate is made, via sampling, of the average crop yield in an agricultural region (e.g., Brazil). Farm 
losses are modeled with actuarial methods (given detailed and long-term data). Successful index insurance is characterized by a high level of transparency and rapid payment after the index has been triggered (both are a problem in traditional harvest insurance, which requires assessment of actual losses by an expert).

Besides, to be effective, the index used must be highly (and spatially) correlated with the damage that farmers actually incur (in order to avoid basis risk). Thus, the literature shows examples whereby the index consists of several risk variables (Dos Santos, 2010, example from India). Furthermore, to counter basis risk, the places where the index is being monitored (i.e., weather stations) must be sufficiently close to the farmers. This can be a problem in countries with many different sub-climates like Ethiopia. Also, such weather stations must be of high quality, make very frequent measurements, and preferably transmit these in real-time to a base station for analysis. To facilitate acceptance by farmers, the index must be easily and objectively observable and understood by all (Gashayie, 2015).

Financial institutions are reluctant to launch weather-indexed insurance schemes to smallholders in the Ethiopian context. However, there is the Ethiopian Project on Interlinking Insurance with Credit in Agriculture (EPIICA) that works with Dashen Bank and Nyala Insurance Company (NISCO). These institutions have started and engaged in the Amhara region with smallholders in high productivity potential as target areas (Mcintosh et al., 2013). But all are still at their infant stage since the approach is new to smallholders. The insurance scheme demands rigorous data on the level of climate risk level, the measures smallholders took to protect the impact, detailed estimation of the damage to be linked with the insurance payment, and all such activities require a wellestablished and functional weather station and highly trained staff, particularly on loss estimation due to climate change risks, and who is willing to work there in the smallholders' vicinity.

\subsubsection{Microfinance institutions (MFIs)}

Without the establishment of MFIs, no developing nation can achieve viable economic growth/development or the reduction of poverty since they lack enough money. MFIs can play a role in the reduction of poverty and improving the socio-economic condition of the poor since there is a positive contribution of MFIs and social development, in which there is better access to health, education, and basic services and greater social respect (Geremewe, 2019). The contribution of education level and entrepreneurial skills has a positive impact on poverty reduction in which there is an increase in income, better living conditions, and better access to basic needs.

Providing financial services tailored to the needs of small borrowers is a high-cost business, as it requires considerable monitoring and enforcement costs. Due to the cost it entails, conventional banks in most developing countries often exclude small borrowers from accessing financial services. Microfinance emerged as institutional innovation to overcome prevailing costs of market contracts and constraints in credit markets of low-income communities where such costs are substantial.

Literature indicated that microfinance industries plan a significant role in improving the livelihood of women and other rural poor in such industries. For instance, Mori \& Randoy (2011) witnessed that the microfinance industry is a unique field in different aspects such as its newness, its diverse organizational structure, and its social mission in which it largely focuses on women and the poor. Fersi \& Boujelbene (2016) also acknowledged microfinance mechanisms that provide access to financial services to poor people who are excluded from the formal financial system.

The revolution and expansion of MFIs in Ethiopia entertained multiple arguments pointing at the factors that facilitated the fast rate of expansion and reasons to flourish. Some argued that the expansion of the MFIs was unprecedented and attributed to the government act in enforcing smallholders to buy fertilizers in the name of development through loans that have been attached with MFIs (Planel, 2021). In their argument, Planel (2021) revealed that forcing smallholders to buy fertilizer which is considered a norm, brought about a newer opportunity to strengthen the regional MFIs in the four regional states (Tigrai, Amhara, Oromiya, and SNNPRS). At the beginning of their establishment, these regional MFIs were serving the political-party affiliated individuals and, later on, during the GTP period, the MFIs left the informal sanction and started serving the entire majority in the egalitarian sense without any social distinction (Planel, 2021).

On the reverse angle, the absence of formal financial institutions aimed at providing loans for the development of smallholder majorities triggered the MFIs to flourish at a faster rate. Ramanaiah and Gowri (2011) mentioned that the DBE and the CBE provide virtually no access to the rural population in terms of micro-credit schemes since they all are located in urban and semi-urban towns as well as the absence of structure to perform the duty. Besides, private banks perform and open their branches in areas where active business and financial flows exist and are not willing to engage in loan delivery for smallholder farmers. The formal financial institutions, especially the commercial ones, often tend to allocate their loans to less risky sectors and discriminate against smallholders and other rural poor. Klerk (2008) revealed the much larger credit share allocated to trade activities by the formal institutions when compared with that of the share of agricultural production, agro-processing, or other rural enterprises.

Some other thought links the start and penetration of MFIs with the shift of the country's economic development structure into capitalism (Kumarl, 2018). Capitalism advocates a free-market economy in various 
sectors including finance and limiting the state involvement in security and some other social service endeavors. Therefore, the gradual and slight shift is being observed by the Ethiopian government, it seems that the economic development pathways are lining towards the capitalist structure.

\begin{tabular}{cll} 
Table 2. & Category 'A' MFIs in Ethiopia & \\
\hline S/N & Name of the institution & Total Assets in 000's \\
\hline 1 & Amhara credit and savings institution & $27,062,094.2$ \\
2 & Dedebit credit and savings institution & $7,969,143.5$ \\
3 & Oromiya credit and savings institution & $12,280,474.5$ \\
4 & Omo credit and savings institution & $8,628,254.8$ \\
5 & Addis credit \&savings institution & $3,955,744.30$ \\
\hline & Total & $59,895,711.3$
\end{tabular}

Source: Ayele (2019).

\subsubsection{Effectiveness of MFIs in smallholders' development}

MFIs are tremendously contributing to the smallholders' development in the country even if they have limitation with respect to outreach and sustainability. Wassie et al. (2019) confirmed that the performances of MFIs in Ethiopia are considered good when compared with the 10 biggest economies in SSA considering their outreach and financial performance metrics. Similarly, the result from financial performance measurement indicates that MFIs in Ethiopia have the highest operational self-sufficiency compared with all the regional averages. The achievement in social performances of MFIs varies and the variation depends on the asset holding, the staff number and their productivity, and the yield on gross portfolio has a significant effect on the social performance of MFIs in Ethiopia (Wassie et al., 2019).

The size and age of the institutions are other factors driving the performance of MFIs. Specifically, bigger MFIs tend to have better financial performance (Ferro-Luzzi \& Weber, 2011; Vanroose \& D'Espallier, 2013) and outreach (Assefa et al., 2013; Vanroose \& D'Espallier, 2013) than smaller MFIs. That means except a few older and larger MFIs, majorities are inefficient in terms of meeting financial and social targets through outreach. The long-stayed voluntary deposit mobilization may help MFIs achieve independence from donors and investors, which is particularly important in periods of liquidity constraints. Besides, the positive relationship between age and financial performance of MFI in Ethiopia implies that as MFIs mature and thus get experience in their industry, they increase their likelihood of attaining financial performance. This can be explained by the fact that MFIs gradually improve their control over all operations related to the issuance of microcredit and their critical activities. (Kumarl, 2018). Mobilization of savings may therefore lead to greater profitability since it provides MFIs with and inexpensive and sustainable source of funds for lending. Deposit may however require widespread branching and other expenses (Muriu, 2011).

\subsubsection{Challenges of MFIs in serving smallholders}

The main distinctive characteristics of MFIs in which they are established in the financial market include the provision of financial services to the poor and attaining financial sustainability. As it is mentioned by Tsegaye (2009) qtd in Wassie et al. (2019) and Oljira (2016), MFIs are required to fulfill the demands from welfarists and institutionalists schools of thought. Welfarists advocate the outreach of financial service to the poor and aimed at improving their wellbeing whereas institutionalists emphasize financial sustainability through profits. Therefore, unlike other formal sectors, MFIs face challenges from both angles.

Evidence shows that MFIs started their loan service that is funded by donors (Ireland and Oxfam) and through the rural financial intermediation programs of the DBE (BeklentIlerİ \& Alemu, 2018; Oljira, 2016) aiming to eradicate poverty from the country. However, lack of capital remains the main challenge as claimed by the MFIs to expand their outreach. Thus, the effectiveness of MFIs was measured according to the number of poor reached and the impact brought on them. On the other hand, when time goes on, MFIs get advanced and the donor fund is ending coupled with the poor saving habit of the society (Beklentilerİ \& Alemu, 2018), they are highly required to be sustainable with their own strategies through raising funds to be financially viable. Therefore, MFIs start covering their own cost of operation from their program revenues and shift themselves from the 'poverty lending' approach to an institution-oriented 'financial systems' approach (Assefa et al., 2013).

Thus, they start charging higher interest rates than the formal banking systems. As it is indicated by Christoph and Richard (2008), the global average interest is about 35 percent and it is below 20 percent in Ethiopia. This is due to the fact that lower operating costs ( 9.4 percent) since operating costs always have been the main driver of MFIs' interest rates. The cost for operating cost has been subsidized in-kind (governmental MFIs get some of their staff paid by local government and are allowed to use rent-free public buildings for operating their branches). The enormous government involvement in Ethiopia's MFI industry resulting in lower interest rates and thereby claimed as indicating that poverty lending is pervasive in Ethiopia.

The cost items that are expected to be covered by the interest rates are the cost of money lent, the cost of defaulted loans, and the transaction cost. In addition, the inexpensive funding and lower staff salaries can partly explain the low-interest rates on loans existent in most of the MFIs in Ethiopia (Weidmaier et al., 2008 qtd in 
Ayalew, 2014). Such MFIs will be forced to increase interest rates for their loans if the government ceases subsidy and is left with two options, either continue with higher rates of interest that possibly result in mission drift or shut down and get out of the financial market. Though MFIs are expanding their services to the poor in various parts of the country, mission drift is being experienced since they are gradually tending to focus on better-offs to sustain them. Gelaw (2019) revealed that MFIs are gradually shifting their services away from their traditional primary targets (poor households) toward better-offs and even large-scale investors to generate more profit. Hence, MFIs, once set up and independent, should be able to generate "win-win" outcomes, whereby both efficiency and equity are enhanced. Very often, however, and depending on some exogenous factors, like infrastructure or access to markets, microcredit must be subsidized to ensure the survival of the MFIs (Ferro-Luzzi \& Weber, 2011).

Credit is considered one of the main obstacles to smallholder development (Brehanu \& Fufa, 2008). It is obvious that access to adequate finance is limited. However, even if such limited financial services are available, a high default rate is one of the major concerns of financial institutions in less developed countries and Ethiopia is not an exception (Brehanu \& Fufa, 2008). Default rates on loans for group lending were less than the individual lending schemes for the MFIs in Ethiopia (Brehanu \& Fufa, 2008) since it establishes strong personal relationships with clients as well as by using other forms of collateral, such as group lending, which generates social collateral (Assefa et al., 2013). However, it is argued that the default rate is higher even with smallholders' group lending schemes due to the nature and context of their agricultural business (Oljira, 2016). The incomes of the smallholders depend on the seasonality of agriculture, their agriculture is predominantly rain-fed which is exposed and susceptible to climate change risks. The climate variability does not only affect the default rate for loans, but also it affects the smallholders 'credit uptake from MFIs (Abay et al., 2021).

Generally, the common causes for the higher default rate are improper group member selection, ineffective repayment enforcement mechanism, absence of effective group pressure or collateral, negligence of clients, crop failure in rural areas, shocks on borrower family members (natural, sickness, and death), and bankruptcy in the business of clients (Kereta, 2007). However, recently the government has decided to move to a system whereby farmers can purchase fertilizer only in cash. This creates an opportunity for well-off farmers who can get inputs based on their demand and that possibly result in a reduced default rate for MFIs (Mcintosh et al., 2013). Moreover, the system makes the utilization of inputs to be dependent on available cash flow to the farmers and the readiness of MFIs with available cash to be disbursed.

The higher rates of illiteracy, especially in rural areas, are increasingly attributed to assessing the credit risk and profitability of loans and savings. On some occasions, MFIs that are willing to work in smallholders' vicinity may lack the motivated and trained staff to work in rural areas. There are also circumstances that (BeklentİlerI \& Alemu, 2018) most of the board members of MFIs are not real investors, there is a carelessness to see and control the operations seriously. This leads to poor institutional capacity among rural financial institutions, especially in developing countries. The absence of specific skill training for borrowers in business areas, insufficient support from the government, limited management capacity of microfinance institutions, improper regulations, and limited management capacity of microfinance institutions (Geremewe, 2019) are some challenges that are facing MFIs that can be a cause for other complications.

Despite MFIs registered remarkable achievements, they suffer from challenges as donors are refused or reluctant to fund, limited loan products, lack of legal entitlements for assets in rural areas, less willingness from commercial banks to lend to MFIs, the organizational structure of the institutions, efficient and competent team, lack of infrastructure, and the absence of legal environment in enforcing the loan contract (Afework \& Endrias, 2016; Beklentİlerİ \& Alemu, 2018; Kereta, 2007).

Therefore, regardless of the fact that the government of Ethiopia considered the MFIs as an nti-poverty strategy and believed to be one important entry point to have income-earning opportunities, ensure empowerment of the poor in the sphere of state/social institutions, and security against a variety of shocks, services are limited in some urban and semi-urban areas, neglecting the majority of the smallholder farming communities.

Generally, financial institutions are reluctant to expand their services into rural areas where dominant smallholder agriculture persists. As is mentioned by Amha and Peck (2010) that the profitability of financial institutions in agriculture is low due to limited economies of scale, higher transaction costs, "lumpy" repayments, illiquid and perishable collateral, risky cash flows, physically dispersed clients living in difficult to reach locations, and diverse sub-businesses with distinct dynamics. In addition, offering financial services to rural households operating in risky contexts where agriculture is predominantly rain-fed involves additional costs and challenges.

\subsection{Semi-Formal Financial Institutions}

\subsubsection{Rural saving and credit cooperative organizations (RuSACCOs)}

Rural saving and credit cooperative organizations (RuSACCOs) are another type of semi-formal financial institution that assists smallholders to boost productivity and improve livelihoods in Ethiopia. Their main focus is neither profit nor charity, rather serving members at fair profit margins. They are much preferred by smallholders than other financial institutions in that interest rates on both savings and loans are generally smaller due to lower 
transaction costs since most of the work is done by voluntary members (Girma Jirata and Jiqin Han, 2018). Its closeness to clients, membership homogeneity, coupled with tax exemptions play a paramount role in the sustainability of RuSACCOs. Moreover, lending upon savings allows RuSACCOs to control their growth and avoid over-indebtedness since they lend the money that is needed by their members (Girma Jirata and Jiqin Han, 2018).

In RuSACCOs, members are owners and, at the same time, customers of the business and are involved in decision-making. This provides the advantage of creating an optimal balance between the institutional and clients' interests. Moreover, its rural location, absence of information asymmetry, and door-to-door deposit collection make it easy to be accessed by smallholders. In addition, unlike other financial institutions, the risk is very low since members mobilize their own resources (Girma Jirata and Jiqin Han, 2018).

The main source of capital for RuSACCOs includes members' savings, interest from loans and reserves, membership fees, service charges, and commissions (Birchall, 2013; Emana, 2009). Interest income is the amount of money received from borrowers (excluding principal), stated as a percentage of the loan amount. Service charges represent fees charged to clients for loan disbursement and other services associated with the loan and savings activities. Sometimes RuSACCOs obtain income from external sources. Emana (2009) revealed that government, NGO funds, formal banks, MFIs, deposits from non-members, other cooperative associations, and community organizations are serving as an external source of income for RuSACCOs.

The number of RuSACCOs and their client rural households have grown in Ethiopia at exponential rates, of 17.9\% and 14.4\% per annum respectively since 1997 (Gelaw, 2019; Girma and Jiqin, 2018). Oromia, Amhara, Tigray, and SNNPRSs, in order of importance, scored the dominant results. However, many of the RuSACCOs are still weak and small, and many of them were established just to absorb external funds and are dependent on the continuous support of cooperative promotion offices (Gelaw, 2019). Besides, like MFIs, RuSACCOs are being blamed for their limitation on extra services, like insurances, rather than credit and savings, and they are not evolving their activities with the advanced IT tools.

The impact of institutional finance on the smallholders' productivity through improving the adoption behavior, in general, is remarkable. Studies revealed that MFIs role in improving productivity through technology adoption is positive only for those who had adequate asset accumulation to further generate growth. On the contrary, those households whose assets are insufficient to generate growth without assistance, do not appear to benefit from MFIs in terms of improved technology use or growth in consumption and assets (Liverpool \& Winter-nelson, 2010). However, RuSACCOs have a greater impact on the adoption of agricultural technologies and input use than the MFIs (Abate et al., 2016) due to, as argued as, the greater degree of trust and social interaction among members and proper screening and incentive compatibility through which members play in screening, monitoring, and enforcing effective use of funds by borrowers. The failure of MFIs, in such cases, attributed to information asymmetry because they lack the information needed to screen the creditworthiness of potential borrowers and monitor them after granting loans (Abay \& Berhane, 2019). Therefore, as argued by Duguma (2018), its easiness and preference, the number of poor reached, and finance mobilized by the RuSACCOs indicate that it is in a better position than the MFIs. In 2016, there were about 14,976 RuSACCOs in rural areas and 7.91 billion Ethiopian birr mobilized by smallholders.

Despite RuSACCOs being better suited to the needs of the rural poor, various factors determine the effectiveness of individual RuSACCO. Evidence indicates that the efficiency of RuSACCos is associated with the maturity level. The study made by Girma and Jiqin (2018) presented that the unit increment of age (in years) of RuSACCOs resulted in a 33\% increment in operational self-sufficiency level indicating that the age of RuSACCOs plays an important role in favor of older ones. This can be articulated as the more experience RuSACCOs gain in deposit mobilization, it accumulates sufficiently adequate capital that improves operational self-sufficiency over a period of years. However, the macro-economic element (inflation) is found in affecting the overall performance of the entire financial sector. Girma and Jiqin (2018) found that the unit percent increment in the price inflation rate decreases the operational self-efficiency of the RuSACCO by $4.23 \%$.

\subsubsection{Challenges facing RuSACCOs in Ethiopia}

RuSACCOs remained the main source of finance for those people who have a low-income level in rural areas. RuSACCOs are considered to have immense potential in financing short-term loans for agricultural technologies and undertake off-farm income-generating activities in rural areas where both the state and the private sector have failed to reach. Cooperatives and socio-economic development in Ethiopia have their own economic significance, employment creation, income generation, poverty reduction, social protection, and cooperative representation (Feleke, 2018). However, like other entities, RuSACCOs also face challenges that hinder their effectiveness in performance. Some of the most important challenges include lack of capacity for providing competent managerial services, limited participation of members in decision-making and controlling activities (because of limited capacity and skill), lack of finance and weak financial management system, weak governance, and basic infrastructure and market information against the need for a better linkage of cooperatives, especially agricultural cooperatives, to markets (Getnet \& Anullo, 2012). 


\subsection{Informal Financial Institutions in Ethiopia}

The informal financial sector in Ethiopia has evolved, through trial and error and without government assistance, into a complex and well-organized financial institution capable of developing self-adjusting mechanisms in the face of changing circumstances (Aredo, 2017). Informal financial institutions, often synonymously called indigenous financial institutions, are predominantly used by the smallholders in rural areas of SSA, including Ethiopia. The most common informal financial institutions that exist in rural areas are Iddir and Iqqub which are considered an integral part of Ethiopia's hidden economy.

\subsubsection{Rotating savings and credit association (Iqqub)}

In its simplest form, Iqqub is a culture of group savings intended usually to raise money to finance large expenses relative to the current income of the members. This includes events (such as weddings, funerals, or religious observances), purchases of household durables and certain types of non-durables, or even for investment purposes (such as the purchase of livestock or fertilizers) and other ventures (such as house construction). Each Iqqub member contributes a certain previously agreed sum to the group every week, month, or quarter, depending on the prior set intervals, and the collected money is given to one person at a time. In some sense, Iqqub undertakes saving and lending activities simultaneously. Typically, members wait for their turn to collect the money raised through such contributions. Customarily, the queue for getting the collected money is established by drawing lots. However, it is also common to arrange it by mutual consent, with the needy coming first. In many ways, Iqqub is a mechanism for group insurance, frequently used to overcome idiosyncratic shocks, and also a form of medium to develop social networks with neighbors. Iqqub is much more common in urban areas than rural areas, where people have a relatively predictable flow of income over the Iqqub period, and a number of mechanisms exist for easy enforcement, including legal remedies (Geda et al., 2008).

Except for slight variations in activities and names, all are considered a type of rotating savings and credit association in SSA. It is Iqqub in Ethiopia, 'Susu' in Ghana, 'Esusu' or 'Ato' in Nigeria, 'Chilemba' or 'Chiperegani' in Malawi, 'Upatu' or 'Mchezo' in Tanzania, and 'Tontiniers' in francophone countries (Teshome, 2008). The capacity of these informal institutions in dealing with financing development ventures that require huge capital is limited. Rather, they meet the needs of its members in fulfilling only household consumption, satisfying production needs, or investments in micro-level businesses.

As is mentioned by Teshome (2015), considering operations, the number of members they incorporate, the cycle period, and their fund allotment mechanisms, two types of Iqqubs identified as traditional/ small scale/ simple Iqqubs and emerging large scale complex Iqqubs. Iqqub plays a dominant role in serving the financial needs of households in urban and rural areas that are excluded from the formal sector due to bureaucratic working processes and high collateral requirements. The default rate for Iqqub's is very low, implying good collateral management and loan screening (Teshome, 2008).

Iqqub consists of but is not limited to, a homogenous group of people from the same workplace, residence, ethnic background, trade, schooling background, and others. Iqqub is being gradually evolved from the customary practices to the modern and legally framed type of institution that is getting more linked with the formal banking system as well as legally binding rules and regulations through which anybody, regardless of background, who is interested in saving and obtaining premium interest at the end of the date while the remaining capital is being shared equally as 'dividends' with all members.

$I q q u b$ is considered as the 'poor man's bank', where money is not idle for long but changes hands rapidly. Unlike other financial institutions, Iqqub does not only provide financial benefits but also plays a key role in social cohesion. As the performances, Iqqub described by Teshome (2015), as a group of individuals meet together on a regular basis (say once a month or once a week) and contribute some fixed amount of money, decided either mutually or by the leader of the Iqqub, into a 'pot' every time they meet. At the end of each meeting, one member of the group is selected to receive the pot. This can be done either randomly or by bidding. This process continues till every member of the group receives the pot of money once. Obviously, those members who have already received the pot earlier cannot receive the pot again, though they still have to contribute to the pot. When every member of the group has received the pot of money once, the group is disbanded, or can be started again with different members, different contributions, and a possibly different duration between subsequent meetings.

It is the most transparent and adaptive to any social group either in urban or rural areas, literate or illiterate, males or females. Additionally, lower transaction costs, responsiveness for immediate needs, and social network pulls some smallholders to take part in Iqqub (Toka \& Asha, 2019). Every member declares the transparency of processes during collection and drawing for the pot winner for the particular day and which has to be conducted in front of all members. It is the alternative method to the areas where the formal and semi-formal financial institutions failed to reach, especially, the rural areas. Most of these transactions are made through the common cultural background and mutual obligations and fervent bonds of family and kinship, all operate to promote the trust, accountability, and moral responsibility that is lacking in the official banking system (Obo, 2009; Teshome, 2008).

Moreover, the fact that collateral is rarely used in the Iqqub and that the sector is almost very free from the 
central bank and government controls enable it to flexibly satisfy financial needs that cannot be met by the formal financial institutions. Therefore, smallholders and private businesses prefer Iqqub rather than formal financial institutions mainly due to obtaining credit without interest (Abdul et al., 2016). The trustfulness of the members for the rules they agreed on and accepting person for collateral instead of collateral for a fixed assets are the experiences to be learned from Iqqub by formal financial institutions and government.

\subsubsection{Social association (Iddir)}

Iddir is defined as "An association made up of a group of persons united by ties of family and friendship, by living in the same district, by jobs, or by belonging to the same ethnic group, and has an object of providing mutual aid and financial assistance in certain circumstances. In practice, the Iddir is a sort of insurance program run by a community or a group to meet emergency situations." Iddir serves as a buffer to shocks that possibly can drain out or diminish the productive asset bases of smallholders through social support mechanisms. Consequently, despite Iddir is not commonly experienced in credit services, it facilitates the enhancement of smallholders' resilience capacity to vulnerability contexts that affect the livelihoods.

There are four types of Iddir operating in either urban or rural areas. These are a community (or territorial, refer ring to people living in the same vicinity), work-place occupational (referring to people working in the same institution), friends' Iddir (referring to former schoolmates or people having close friendship), and family Iddir (involving blood relatives or very close friends) (Aredo, 2017). It has been observed that "despite the abundance and vitality of these institutions the development agencies appear to have overlooked them as partners or tools in their work." Each Iddir has its own by-laws and book-keeping system (Aredo, 2017).

According to Salole (1986) the original purpose of the Iddir, an institution indigenous to Ethiopia, was the burial of the dead. Today, the Iddir provides a much wider range of services including financial and material assistance and consolations to a member in the event of difficulties as well as entertainment as the case may be.

Iddir is considered a mutual aid association and serves in most cases the social objective of supporting the members in covering funeral expenses, financial assistance to families of the deceased, in some cases, coverage of other risks such as medical expenses, losses due to fire or theft, wedding or other social needs that require mutual assistance (including one or a combination of contributions of labor, food and drink, and consolation of the family during mourning, money from the common pool) as may be defined in the by-laws of the Iddir. Almost every Iddir has its own by-laws providing duties and rights of members, procedures, and functions of officials which is endorsed by the general assembly.

Social ties are very important in Iddir. A member is required to attend meetings, be present at funeral ceremonies, visit the sick, etc. The by-laws of Iddir are observed because of powerful social sanctions and fines. Members' contributions vary from Iddir to Iddir. The fund collected from members is deposited in the bank in cases of urban and semi-urban areas and only a small amount is kept with the officials for emergency purposes. In remote rural areas where formal banks do not exist, savings collected from members is commonly been kept in the houses of the cashier. Most Iddirs have their own tents, benches or chairs, utensils, etc. These materials are used mainly in the event of the death of a family member of a participant.

The Iddir is perhaps the most egalitarian and democratic grass-roots level institution in Ethiopia. It cuts across ethnic, religious, and occupational boundaries. Thus, it has great potential for the social, economic and political development of the country. It is easy for the government to reach the members of Iddir through leaders who are the most trusted by members. The study suggests that the Iddir, unlike the insurance system, is very popular among rural people. It is attractive to the people because it is culture-appropriate, flexible, easily accessible and costeffective. Unlike the insurance system, it is a non-profit-making institution based upon solidarity, friendship, and mutual assistance among members. People from all walks of life participate in the Iddir. The insurance system, on the other hand, is limited to high households seeking insurance policies for a definite purpose (Aredo, 2017).

In a society where monetary relations have not yet been sufficiently developed, culturally appropriate financial institutions will remain indispensable. People who might not qualify for bank loans or insurance policies resort to the Iddir. Interestingly enough, even those who do qualify for these facilities still use the Iddir due to the additional benefits they get from these institutions. Social solidarity and friendship are among such benefits. Moreover, the informal sector appears to have better access to information about the creditworthiness of a participant than the formal sector.

\subsubsection{Forms of Iddir}

There are a variety of practices that resemble Iddir and its aims in various parts of the country. The Borana Oromo pastoralists have an indigenous social insurance scheme that parallels the Iddir of the rural and urban people. They are bound by customary law to contribute cattle to restore a person's wealth with cattle in case of death of animals by natural calamities or if cattle are looted. The practice is called Buusa Gonofaa, which approximately means "contribution against devastation" (Obo, 2009). Another traditional financial arrangement is common in the rural Wolaita and called Masqallaa Amuwwaa in which members of a community residing in the same locality save money by contributing to a common pool for the purpose of purchasing fattened ox at the 'meskel' festival and which reduce the burden of festival expenditure by spreading it over a year. 
This indicates that there are ample untapped opportunities for MFIs in various parts of rural Ethiopia to expand their financial services and these local institutions can be a vehicle to mobilize savings and to expand the scope of savings to include other basic expenditures, such as housing, for which MFIs could lend after a client has saved some amount. There is an option that the informal institutions could also be evolved to village banking, depending on the strength of the association, which could eventually reduce the transaction costs of lending. However, there has been little effort on the part of MFIs in Ethiopia to link their operations with traditional institutions (Obo, 2009).

\subsection{The Role of Informal Financial Institutions in Smallholders' Development}

The paucity of finance is one of the impediments that severely hinder the development of smallholder agriculture in SSA, especially in Ethiopia. This is mainly due to, as it is noted by Wassie et al. (2019), most of the conventional banks in the country are concentrated in urban areas and whenever available, they systematically exclude the rural poor due to the higher screening, monitoring, and enforcement costs of providing a small loan.

Smallholders need to finance to invest in their livelihood enhancing activities, especially in purchasing improved seeds and chemical fertilizer to boost their productivity and as startup capital for micro-enterprises in their locality. As it has been discussed above, the limitations of formal financial institutions in outreaching the vast majority of smallholders who live in remote areas where infrastructural facilities are deprived off, informal financial institutions play a paramount role in the development of smallholders' agriculture that has been overlooked by the formal financial institutions.

Due to flexibility, informality, proximity, culture-appropriateness, and other special features of the informal financial institutions complemented with the widespread prevalence of informal financial sources attract the smallholders in Ethiopia (Gurmessa \& Ndinda, 2017) since as the empirical evidence indicated that the loan products of most financial institutions are not appropriate for smallholder agricultural activities. Therefore, smallholders, unlike other population segments, do not prefer formal financial institutions to get loans. Consequently, smallholders in Southwest Ethiopia are found improving their households' food security status through participation in informal financial institutions, particularly, in Iqqub (Negera et al., 2019).

\subsection{Trade-offs of the Informal Financial Institutions}

Despite the positive role informal financial institutions play in the development of smallholders in buffering and filling gaps that could not be reached by the formal financial institutions, they have inherent weaknesses. The informal institutions are mostly located in certain areas of rural, semi-urban, and urban and comprised of individuals who have some form or other relation with each other. As a result, most of the informal institutions are fragmented and control limited financial resources. Consequently, their capacity to make credit available to the tune and at the time required by borrowers is very limited. Hence they have limited capacity to enhance agricultural investment thereby improving smallholders' livelihoods. In some areas, especially urban and semi-urban, informal institutions are closely linked with the formal institutions only through deposit services and insurances.

\section{CONCLUSION AND POLICY IMPLICATIONS}

\subsection{Conclusion}

The achievement of smallholders' development in SSA including Ethiopia through agricultural intensification, small-scale irrigation, improved technology, and commercialization is widely perceived as a key strategy for rural development, poverty reduction, and food security. These strategies require intensive utilization of improved agricultural practices, inputs (improved seeds, inorganic fertilizers, pesticides, insecticides, herbicides, fungicides, etc.), and modern mechanical implements. The utilization of such improved technologies is determined by, among others, access to technology and financial access from financial institutions.

Smallholders in the country are known for their resource deficiency, particularly finance, to achieve agricultural transformation so as to boost productivity to feed the increasing population, serve as raw material for domestic agro-based industries, and supply for the export market to get foreign currency. Therefore, financial institutions play a paramount role in this regard through various forms such as saving mobilization, credit supply, facilitating the establishment of agro-industries and enterprises in rural areas, and insurance.

Having realized, GoE had gone a long way to liberalize the financial sector through devising financial inclusion policy to reach neglected and exclude poor and smallholder population segments. The financial sector (formal, semi-formal, and informal) has been expanding with their internal structures, branch numbers, assets, capitals, and clients. Besides, newer actors and financial institutions are emerging and the sector is becoming competitive hence trying to attract and retain more clients with advanced forms of services.

Formal financial institutions are reluctant to engage in services directly on smallholders' saving and credit endeavors except for the MFIs due to the risky nature of their agricultural business and the commercial design of the institutions. Traditionally, banks and other formal financial service providers, such as insurance companies, have not considered the poor a viable market, and penetration rates for formal financial services in developing 
countries are extremely low. This is mainly because of limited access, as lending to these smallholders remains unattractive to conventional commercial lenders due to small transaction size, covariant risk, and geographical remoteness of dispersed farmers. However, the formal financial institutions in the country are not serving the rural population directly, rather serve indirectly through delivering credit for rural-based medium/large-scale industries that create a market for smallholders' agricultural products through raw material and smallholders get engaged through wage labor during the lean season so as to increase their income. Additionally, despite the formal financial institutions have not devised a system that encourages smallholders to get credit directly, they, particularly the $\mathrm{CBE}$ and $\mathrm{DBE}$, reach smallholders through lending huge finance to region-specific MFIs in order to implement their poverty lending approach that encompasses services for smallholders.

The formal institutions are mobilizing savings through encouraging the opening of bank accounts by adults where they are functioning (urban and semi-urban settings) and the number of adults assessing the formal banking service is increasing from time to time and such institutions are also being evolved through ICT technologies like mobile banking, ATM, pose machines, etc. However, since the formal financial institutions are concentrated and confined in urban and semi-urban areas, their services are limited to the people who live around their branches and headquarter offices.

MFIs are, based on their poverty lending theme, the most serving institutions that smallholders and the poor obtain loans. These institutions emerged in the country through a series of proclamations geared to financial inclusion policy and financial liberation. It is not only smallholders who obtain loans but also serve as a source of finance for startup capital for urban and rural SMEs. Their effort is tremendous in the country through state-owned big MFIs and they are continually growing in terms of capita, assets, and clients. The growth and advancement of these institutions are due to the fact that the compulsory fertilizer dispatch has been linked as the fertilizer credit by the government.

Comparatively, they were doing well in smallholders' development in facilitating the provision of credit to get yield boosting technologies and inputs. Despite the MFIs are established to reduce poverty in rural areas and facilitate the rural transformation, their outreach to smallholders and coverage is below expectation and their services are incompatible with the smallholders' contexts in their demand for the fixed assets as collateral that smallholders cannot afford due to the land tenure system of the country.

Nonetheless, most MFIs and RuSACCOs in Ethiopia are very small in size and lack the capacity to facilitate large loans for indivisible agricultural investments (for example, tractors, tube well, oxen, and so on). Most lend small amounts aimed at increasing the productivity and income of small farmers through enabling them to adopt divisible technologies, such as improved seeds and fertilizer.

MFIs have devised group lending schemes as the only strategy to reach smallholders using group members as collateral to minimize defaults through the social obligation to enforce loan repayment. However, those on whom people have no confidence that they can repay their loans are devoid of membership in group formation remain neglected from obtaining loans. Smallholders can be served in more coverage through a variety of approaches as a mobile banker, satellite ban, branchless banks, etc. like other countries. Besides, due to lengthy bureaucracy, elaborated paperwork, a one-size-fits-all approach, and smaller loan products, a substantial number of smallholders are out of the credit and saving services due to supply-side limitations and less demand. Moreover, it is not common to see MFIs, except Addis credit and saving MFI, advancing their services through ICT technologies like mobile banking, online transactions, and others that facilitate in reducing transaction costs.

Despite WII endeavors being legally driven, almost all financial institutions are unenthusiastic to engage in a micro-insurance product that assists smallholders during climate-induced risks except Dashen bank and Nyala insurance company. Even though these institutions have started micro-insurance schemes only in Amhara regional state, WII can be regarded an infant at the national level. Regardless of the fact that MFIs are allowed to perform micro-insurance, they did not start the service yet. Therefore, smallholders can be reached not only through conventional saving and credit services but also can serve as sources of market and opportunity for financial institutions through micro-insurance schemes. There is a large unmet need with regard to simple, cheap protection against weather risks. However, other types of insurance, especially life insurance, are also lacking. Due to a lack of formal insurance, many Ethiopian households have turned to risk-mitigating schemes offered by the informal financial market.

Flexibility, informality, proximity, and culture-appropriateness of informal financial institutions coupled with service incompatibility by the formal financial institutions, a significant portion of smallholders prefer the informal sector to fix their financial demands. The informal institutions are evolving to more legally binding systems and being linked in current times following the expansion of branches from the formal sector. The services outputs from informal financial institutions are not limited to finances rather stretche to social values. However, informal institutions existing far away from the formal bank branch areas still keep the finance with their homes till disbursed to the needy ones according to their by-laws. Most loans from informal sources especially from money lenders are too expensive to be profitable, and debt can lead to the permanent dependency of borrowers on money lenders and thereby entangle in the vicious cycle of poverty. Moreover, loans from informal financial institutions 
are deficient and unreliable in covering risks of debilitating illness of a family income earner and long-term investment credit, particularly to move to higher-value-added crops and business models. Furthermore, they tend to be unreliable.

Most of the time, informal financial institutions' by-laws and book-keeping systems of the informal institutions are not up-to-date and thus open a loophole for vandals and expose them to exploitation, theft, embezzlement, and mismanagement by swindlers and unethical elite leaders. Smallholders' informal institutions are lacking linkages with the formal sector that can create an opportunity to grasp lessons on how to manage finance. However, not much has been done by the formal institutions to integrate the informal institutions in their activities, and they have not used them as a partner or tool to enhance their operations to achieve the smallholders' development in the country.

\subsection{Policy implications}

The financial institutions are evolving and expanding their services to rural areas where smallholder agriculture is dominant. However, smallholders are the most excluded segment from the formal financial sector and the outreach of such institutions is limited around urban and semi-urban settings due to internal, external, and both reasons. Therefore, to achieve the development of smallholders in the country, the following policy and strategic issues are required to be in place.

Improving capacities of MFIs and RuSACCOs to facilitate the outreach to smallholders with intensive ambition through setting the appropriate incentives for them to serve the rural poor, providing loans for these institutions to be available for smallholders, linking the need-based input credit, designing a credit guarantee scheme, building the administrative capacities of the leaders, linking these institutions with other government payment schemes such as HABP, PSNP, WII, health insurances, pension, and enhancing their internal service delivery through ICT packages to reduce the transaction costs for smallholders. Besides, improving the regulatory environment for rural financial institutions including RuSACCOs is needed. Financial institutions are required to re-engineer their service delivery as well as modify their lending process through customizing loan amount, payment schedule, and interest rates considering the payment capacity of the smallholder clients.

The MFIs and RuSACCOs have to design a strategy and internal structure to reach smallholders through mobile loan officers, branchless banking, and monitoring and clients whether they are using the loan on productive business ventures or not to decrease default rates. Mobile loan officers travel from the bank location to rural clients following an established routine and itinerary and serve as intermediaries between the bank and the clients. The assignment of the mobile officers to distinct operational zones can create efficiencies and other positive externalities in the creation of employment opportunities for unemployed youths.

Financial services with diverse and flexible products and terms are needed if the financial requirements of the different strata of the farming community are to be properly met. The credit product is required to be responsive to the distinctive features and demand level of commercial, semi-commercial, and subsistence smallholders through the classification of smallholders.

The startup and scaling up of insurance, particularly weather indexed insurance on a micro-insurance platform with the regulatory framework, is an essential component in the development of smallholders that assist them during different vulnerability contexts. The WII requires accurate climate data and skilled personnel who perform all the duties associated with loss estimation and some other details. Therefore, GoE and NGOs need to upgrade the meteorological technical infrastructure as well as the capabilities of meteorological personnel, in order to collect the required weather data quickly and reliably.

Further liberalization of the financial institutions through the appropriate regulatory system is essential to have an easy entry for domestic banks in reach smallholders and the rural poor through the emergence of newer financial institutions. Besides, stimulating competition in the Ethiopian financial institutions by providing a conducive legal environment to encourage them to provide services with concessional interest rates, improved service delivery, and credit amounts based on demand.

Strong linkage among formal institutions and linkage of formal with informal financial institutions is essential. This helps in mobilizing financial resources to be deposited in formal institutions and to be used as credit services. As it is known, some amount of money is withdrawn only during circumstances that members face like death, illness, and others and until then, the money remains idle in informal financial institutions, especially Iddir and Iqqub. Such money can be utilized and invested in productive areas that bring development in the form of loans for smallholders instead by MFIs and RuSACCOs. This can be an option and opportunity in solving the limited loan product that financial institutions often encounter. This requires the ingenuity of the formal institutions and monetary authorities to create enabling environment and tap the resources in the hand of the informal institutions, and also make use of them to gather resources for the best use.

Integrated systems development approach such as agricultural sector policy which supports agricultural sector income potential; financial sector policy which supports financial institution sustainability; buildup of financespecific and general infrastructure which breaks production bottlenecks, reduces production risk and bolsters the 
return to capital; human capital and management development and capital market development, for both external and internal sources of capital.

Agricultural productivity can be improved if financial institutions are willing to modify the rules and regulations that govern the requirements for collateral and the procedures involved for borrowing by small farmers.

It is imperative that the informal financial institutions can emerge as rural banks through coordination and can design a loan product that can best respond to its members' needs. The coordination and pulling of resources can be through a share of capital formation from an individual informal financial institution.

With appropriate government policies, it may be possible to gradually transform existing "traditional" financial institutions into modern ones. The realization of the potentials of existing informal financial institutions depends, to a great extent, on the degree of appropriateness and effectiveness of government policies. Existing policy constraints need to be removed. More government support should be given like training programs on making legally acceptable by-laws, agreement letters, record keeping, and financial management. The creation of a strong relationship with commercial banks and informal financial institutions will help to strengthen the rural financial system and to build an internally well-integrated national financial structure.

\section{REFRENCE}

Abate, G. T., Rashid, S., Borzaga, C., \& Getnet, K. (2016). Rural Finance and Agricultural Technology Adoption in Ethiopia : Does the Institutional Design of Lending Organizations Matter? World Development, 84, 235253. https://doi.org/10.1016/j.worlddev.2016.03.003

Abay, K. A., \& Berhane, G. (2019). Rural Finance and Smallholder Farming in Ethiopia (Issue March). https://doi.org/10.1093/oxfordhb/9780198814986.013.25

Abay, K. A., Koru, B., Chamberlin, J., \& Berhane, G. (2021). Does rainfall variability explain low uptake of agricultural credit? Evidence from Ethiopia. European Review OfAgricultural Economics, 00(00), 1-26. https://doi.org/10.1093/erae/jbab013

Abdul, S., Pasha, M., Debalke, A., \& Dayrra, D. (2016). Role of 'Iqqubs ' in Private Business Start Up and Development of Smes with Reference to Arba Minch, Ethiopia. 8(2), 41-50.

Abedullah, N. Mahmood, M. K. and S. K. (2009). The Role of Agricultural Credit in the Growth of Livestock Sector: A case study of Faisalabad. Pakistan Vet. J., 29(57), 3.

Adeola, O., \& Evans, O. (2017). Financial inclusion, financial development, and economic diversification in Nigeria. The Journal of Developing Areas, 51(3), 1-15. https://doi.org/10.1353/jda.2017.0057

Aderaw Gashayie and Manjit Singh. (2016). Development of Financial Sector in Ethiopia : Literature Review. 7(7), 9-20.

Admassie, A. (2004). A Review of the Performance of Agricultural Finance in Ethiopia: Pre-and Post Reform Periods.

Afework, H., \& Endrias, G. (2016). Review on small holders agriculture commercialization in Ethiopia: What are the driving factors to focused on? Journal of Development and Agricultural Economics, 8(4), 65-76. https://doi.org/10.5897/jdae2016.0718

Alemu, G. (2016). Financial inclusion, regulation and inclusive growth in Ethiopia. Achieving Financial Stability and Growth in Africa, November, 137-157. https://doi.org/10.4324/9781315648668

Amha, W., \& Peck, D. (2010). Agricultural finance potential in Ethiopia: Constraints and opportunities for enhancing the system (Issue July).

Amogne Mamaw, Abebaw Fisseha, G. Z. (2018). Assessment of the Role of Microfinance on Poverty Reduction in North Shewa Zone Ethiopia. 12(2), 36-47.

Anupam Basu, Rodolphe Blavy, and M. Y. (2004). Microfinance in Africa: Experience and Lessons From Selected African Countries. IMF Working Papers, 04(174), 1. https://doi.org/10.5089/9781451858723.001

Aredo, D. (2017). The Iddir: A study of an indegeneous informal financial institutions in Ethiopia (Vol. 17, Issue 1).

Assefa, E., Hermes, N., \& Meesters, A. (2013). Competition and the performance of Microfinance institutions. Applied Financial Economics, 23(9), 767-782. https://doi.org/10.1080/09603107.2012.754541

Ayalew, G. (2014). Microfinance Institutions in Ethiopia, Kenya, and Uganda: Loan outreach to the poor and the quest for financial viability. The Horn and Social Policy Institute, 02.

Ayele, A. G. (2019). A Study on the Performance of Category 'A 'Microfinance Institutions in Ethiopia. 9(9), 114.

Barslund, M., \& Tarp, F. (2008). Formal and informal rural credit in four provinces of Vietnam. Journal of Development Studies, 44(4), 485-503. https://doi.org/10.1080/00220380801980798

Bastin, A., \& Matteucci, N. (2007). Moving Results into Policies and Practice Financing Coffee Farmers in Jimma Zone, Ethiopia: Challenges and Opportunities. FAO: International Conference on Rural Finance Research: Moving Results into Policies and Practice, January.

Bauchet, J., Marshall, C., Starita, L., Thomas, J., \& Yalouris, A. (2011). Latest Findings from Randomized 
Evaluations of Microfinance. In Access to Finance FoRuM Reports by CGAP and Its Partners (Issue 2). https://doi.org/10.1596/26892

Baza, A. U., \& Rao, K. S. (2017). Financial Inclusion in Ethiopia. International Journal of Economics and Finance, 9(4), 191. https://doi.org/10.5539/ijef.v9n4p191

Beck, T., Senbet, L., \& Simbanegavi, W. (2015). Financial Inclusion and Innovation in Africa: An Overview. Journal of African Economies, 24, i3-i11. https://doi.org/10.1093/jae/eju031

Beklentİlerİ, Z. V. E., \& Alemu, S. (2018). the Performance of Ethiopian Microfinance Institutions, Challenges and Prospects. Karadeniz Teknik Üniversitesi Sosyal Bilimler Enstitüsü Sosyal Bilimler Dergisi, 8(16), 307324.

Bernard, T., \& Spielman, D. J. (2008). Mobilizing Rural Institutions for Sustainable Livelihoods and Equitable Development: A Case Study of Agricultural Marketing and Smallholder Cooperatives in Ethiopia (Issue January).

Birchall, J. (2013). Resilience in a downturn: The power of financial cooperatives (Vol. 148). ILO.

Brehanu, A., \& Fufa, B. (2008). Repayment rate of loans from semi-formal financial institutions among smallscale farmers in Ethiopia: Two-limit Tobit analysis. 37, 2221-2230. https://doi.org/10.1016/j.socec.2008.02.003

Bruhn, M., \& Love, I. (2014). The real impact of improved access to finance: Evidence from mexico. Journal of Finance, 69(3), 1347-1376. https://doi.org/10.1111/jofi.12091

Christoph Kneiding \& Richard Rosenberg. (2008). Variations in Microcredit. World Bank Other Operational Studies, 2006(9510).

Conning, J., \& Udry, C. (2007). Chapter 56 Rural Financial Markets in Developing Countries. Handbook of Agricultural Economics, 3(06), 2857-2908. https://doi.org/10.1016/S1574-0072(06)03056-8

Daniel, D. (2014). The Role of Microfinance Institutions in Accessing Credit and Poverty Reduction in Rural Ethiopia: in the case of Omo microfinance institutions in Damot Gale Woreda, Wolaita Zone. Hawassa University.

de Klerk, T. (2008). The Rural Finance Landscape: A Practitioners Guide. http://www.networklearning.org/index.php/library/the-rural-finance-landscape/112-the-rural-financelandscape-a-practitioner-s-guide-pdf/file

Demirguc-Kunt, A., Klapper, L., Singer, D., \& Van Oudheusden, P. (2015). The Global Findex Database: Measuring financial inclusion around the world. Jurnal Ilmiah Mahasiswa Fakultas Ekonomi Dan Bisnis Universitas Brawijaya, April, 11.

Derek Byerlee, David J. Spielman, Dawit Alemu, and M. G. (2007). Policies to Promote Cereal Intensification in Ethiopia: A Review of Evidence and Experience (Issue June).

Devereux, S. (2000). Food insecurity in Ethiopia. Discussion Paper for DFID, October 2010, 16. http://www.addisvoice.com/wp-content/uploads/2010/03/FoodSecEthiopia4.pdf

Diana, F., Guirkinger, C., \& Boucher, S. (2010). Risk, credit constraints and financial efficiency in Peruvian agriculture. Journal of Development Studies, 46(6), 981-1002. https://doi.org/10.1080/00220380903104974

Diao X., Alemayehu Seyoum, Yu B., P. A. N. (2010). Economic Importance of Agriculture for Sustainable Development and Poverty reduction: the case study of Ethiopia.

Diriba, G. (2020). Agricultural and Rural Transformation in Ethiopia: Obstacles, Triggers and Reform Considerations (Issue January). https://media.africaportal.org/documents/Agricultural_and_rural_transformation_in_Ethiopia.pdf

Dixon John, T.-A. A. and W. H. (2004). Framework For Analysing Impacts Of Globalization On Smallholders. FAO and World Bank.

Doreen Auma and Philip Ahen Mensah. (2014). Determinants of credit access and demand among small-holder farmers in Tigray region, Ethiopia. Norwegian University of Life Science, School of Economics and Business.

Dupas, P., \& Robinson, J. (2013). Daily needs, income targets and labor supply: Evidence from Kenya. In NBER Working Paper Series (No. 19264). http://www.nber.org/papers/w19264

Durie, A. D. (2018). Financing Rural Industrialization and Employment Creation: The case of Ethiopia. INDEPENDENT JOURNAL OF MANAGEMENT \& PRODUCTION, December, 1317-1337. https://doi.org/10.14807/ijmp.v9i4.803

Ebimobowei Appah, M. Sophia John, S. W. (2012). An analysis of microfinance and poverty reduction in bayelsa state of nigeria. Arabian Journal of Business and Management Review, 1(7), 38-57.

Emana, B. (2009). Cooperatives: a path to economic and social empowerment in Ethiopia. In ILO (Ed.), International

Organization

(Issue

9). http://www.ilo.org/public/english/employment/ent/coop/africa/info/publ.htm

Fanzo, J. (2017). From big to small: the significance of smallholder farms in the global food system. The Lancet Planetary Health, 1(1), e15-e16. https://doi.org/10.1016/S2542-5196(17)30011-6 
FAO. (2014a). Family Farmers: Feeding the World, Caring for the Earth.

FAO. (2014b). Why Is Family Farming Important? Feeding the World, (Issue October).

FAO. (2015). The economic lives of smallholder farmers. In FAO Food And Agriculture Organization of the United

Nations. http://www.macrothink.org/journal/index.php/rae/article/view/6320\%0Ahttp://www.upov.int/edocs/mdocs /upov/en/upov_sym_ge_11/upov_sym_ge_11_10.pdf\%0Ahttp://ajae.oxfordjournals.org/cgi/doi/10.2307/1 241587\%0Awww.iosrjournals.org\%0Ahttp://link.springer.com/10.

Feleke, A. (2018). Review on the Role of rural Saving and Credit Cooperatives in Improving Rural Farmers 'Socio -economic Activities in Ethiopia. 01(4).

Ferro-Luzzi, G., \& Weber, S. (2011). Measuring the Performance of Microfinance Institutions. SSRN Electronic Journal, 1-17. https://doi.org/10.2139/ssrn.918750

Franz Heidues, M. B. (2003). Subsistence Agriculture in Development: Its role in process of structural change (22nd ed.). Leibniz Institute of Agricultural Development in Transition Economies (IAMO), Halle (Saale).

Gadasandula, K. B. A. A. (2020). Microfinance Institutions Role in Providing Credit and Poverty Decline In Rural Ethiopia. International Journal of Management (IJM), 11(11), 2650-2670. https://doi.org/10.34218/IJM.11.11.2020.249

Gashayie, A. (2015). Agricultural Finance Constraints and Innovative Models Experience for Ethiopia : Emprical Evidance from Developing Countries. Research Journal of Finance and Accounting, 6(7), 39-50.

Gebreselassie, S. (2006). Land, Land Policy and Scenarios Ethiopia: Options and Smallholder Agriculture in. In Future Agriculture, Discussion Paper 008 (Vol. 94, Issue 6).

Geda, A., Shimeles, A., \& Zerfu, D. (2008). Finance and Poverty in Ethiopia: A Household-Level Analysis.

Gelaw, F. (2019). MFI characteristics and loan preferences of farmers: Household-level evidence from rural Ethiopia. African Journal of Agricultural and Resource Economics, 14(2), 137-151.

Geremew Kefyalew and Toli Jembere. (2016). Formal vis-a-vis Informal Financial Institutions as a Source of Credit for Micro and Small Enterprises in Ethiopia : Empirical Evidence from Wolaita and Dawro zones, Ethiopia. European Journal of Business and Management, 8(10), 8-16.

Geremewe, Y. T. (2019). The Role of Microfinance Institution for Poverty Reduction in Ethiopia. Journal of Economics and Sustainable Development, 10(5), 36-44. https://doi.org/10.7176/JESD

Getnet, K., \& Anullo, T. (2012). Agricultural cooperatives and rural livelihoods: Evidence from Ethiopia. Annals of Public and Cooperative Economics, 83(2), 181-198. https://doi.org/10.1111/j.1467-8292.2012.00460.x

Girma Jirata and Jiqin Han. (2018). Effect of Deposit Mobilization on the Financial Sustainability of Rural Saving and Credit Cooperatives: Evidence from Ethiopia. Sustainability, 10(3387), 1-23. https://doi.org/10.3390/su10103387

Group, W. B. (2020). Ethiopia's Steady Economic Growth Leads to Poverty Reduction. https://www.worldbank.org/en/country/ethiopia/publication/ethiopias-steady-economic-growth-leads-topoverty-reduction,

Gurmessa, N. E., \& Ndinda, C. (2017). Smallholder s 'Access to a nd Demand for Credit and Influencing Factors : Policy and Research Implications for Ethiopia. 4(3), 48-60.

IFAD. (2013). Smallholders, Food Security, and the Environment. IFAD, UNEP.

IMF. (2013). The Federal Democratic Republic of Ethiopia: 2013 Article IV Consultation. IMF Staff Country Reports, 13(308), 1. https://doi.org/10.5089/9781475578997.002

IMF. (2020). Federal Democratic Republic of Ethiopia: the 2019 Article IV Consultation and Requests for ThreeYear Arrangements Under the Extended Credit Facility and the Extended Fund Facility, IMF Country Report. 20, 1-121. https://www.imf.org/en/Publications/CR/Issues/2020/01/28/The-Federal-DemocraticRepublic-of-Ethiopia-2019-Article-IV-Consultation-and-Requests-for-48987

Iqbal, M., Ahmad, M., \& Abbas, K. (2003). The impact of institutional credit on agricultural production in Pakistan. Pakistan Development Review, 42(4 II), 469-483. https://doi.org/10.30541/v42i4iipp.469-485

Irz, X., Lin, L., Thirtle, C., \& Wiggins, S. (2001). Agricultural productivity growth and poverty alleviation. Development Policy Review, 19(4), 449-466. https://doi.org/10.1111/1467-7679.00144

Isaboke, H. N., Qiao, Z., \& Nyarindo, W. N. (2016). Agricultural and Resource Economics: International Scientific E-Journal Agricultural and Resource Economics : International Scientific E-Journal. Agricultural and Resource Economics: International Scientific E-Journal, 2(3), 5-21.

Karlan, D., \& Morduch, J. (2010). Access to finance. In Handbook of Development Economics (1st ed., Vol. 5, Issue C). Elsevier BV. https://doi.org/10.1016/B978-0-444-52944-2.00009-4

Karlan, D., \& Zinman, J. (2010). Expanding credit access: Using randomized supply decisions to estimate the impacts. Review of Financial Studies, 23(1), 433-464. https://doi.org/10.1093/rfs/hhp092

Kassa, B. Y. (2010). Regulation Supervision of Microfinance Business in Ethiopia: Achievements, Challenges and Prospects. International Conference on Microfinance Regulation.

Kereta, B. B. B. (2007). Outreach and Financial Performance Analysis of Microfinance Institutions in Ethiopia 
(Issue November).

Klapper, L., Laeven, L., \& Rajan, R. (2006). Entry regulation as a barrier to entrepreneurship. Journal of Financial Economics, 82(3), 591-629. https://doi.org/10.1016/j.jfineco.2005.09.006

Komicha, H. H. (2007). Farm Household Economic Behaviour in Imperfect Financial Markets. In Evidence And Policy.

Kumarl, A. Y. and B. (2018). As Stusy of Microfinance Institutions and Their Financial Performance with special Reference to Ethiopia. International Journal of Research and Analytical Reviews, 5(April), 315-326.

Lakew, T. B., \& Azadi, H. (2020). Financial Inclusion in Ethiopia : Is It on the Right Track? International Journal of Financial Studie, 8(28), 1-13.

Liverpool, L. S. O., \& Winter-nelson, A. (2010). Poverty Status and the Impact of Formal Credit on Technology Use and Wellbeing among Ethiopian Smallholders. World Development, 38(4), 541-554. https://doi.org/10.1016/j.worlddev.2009.11.006

Mafi, T., Oguntade, A., \& Mafi, O. (2010). Re-Engineering Agriculture For Enhanced Performance through Financing * Restructurando la agricultura para aumento de rendimiento a través del fi nanciamiento. Agricultural Economics, 15(29).

Mamuye, W. (2021). Determinants of Smallholder Farmers Participation in Formal Credit and Challenges Faced by Institutions: The Case of Mojana Wodera District , Amhara Region , Ethiopia. 7(1), 9-20. https://doi.org/10.11648/j.ijfbr.20210701.12

Mcintosh, C., Sarris, A., \& Papadopoulos, F. (2013). Productivity, credit, risk, and the demand for weather index insurance in smallholder agriculture in Ethiopia. 44, 399-417. https://doi.org/10.1111/agec.12024

Mekonen Kassahun and Melesse Asfaw. (2014). Financial Regulation and Supervision in Ethiopia. 5(17), 63-72.

Mersha, D., \& Ayenew, Z. (2018). Financing challenges of smallholder farmers: A study on members of agricultural cooperatives in Southwest. African Journal of Business Management, 12(10), $285-293$. https://doi.org/10.5897/AJBM2018.8517

Morton, J. F. (2007). The impact of climate change on smallholder and subsistence agriculture. Proceedings of the National Academy of Sciences of the United States of America, 104(50), 19680-19685. https://doi.org/10.1073/pnas.0701855104

Mpuga, P. (2010). Constraints in access to and demand for rural credit: Evidence from Uganda. African Development Review, 22(1), 115-148. https://doi.org/10.1111/j.1467-8268.2009.00230.x

Muayila KH, E. T. (2012). Assessing the Impact of Credit Constraints on Farm Household Economic Welfare in the Hinterland of Kinshasa, Democratic Republic Of Congo. 12(3), 6095-6109.

Mulatu, E., Geta, E., \& Melaku, E. (2020). SMALLHOLDER FARMERS' CREDIT PARTICIPATION : THE CASE of OMO MICROFINANCE INSTITUTION in GIMBO DISTRICT of KAFFA ZONE, SOUTHERN ETHIOPIA. Journal of Agricultural Economics and Rural Development, 6(3), 888-898.

Muriu, P. (2011). Microfinance Profitability: Does financing choice matter? Birmingham Business School University of Birmingham, PhD Disser(33), 77-93.

Nagayets, O. (2005). Small Farms: Current Status and Key Trends. Information Brief, 1-14.

NBE. (2020). Ethiopia: Macroeconomic and Social Indicators.

Negera, C. U., Bekele, A. E., \& Wondimagegnehu, B. A. (2019). The Role of Informal Local Institutions in Food Security of Rural Households in Southwest Ethiopia. The International Journal of Community and Social Development, 2(1), 124-144. https://doi.org/10.1177/2516602619853419

Obo, D. D. (2009). MICROFINANCE IN ETHIOPIA: Elixir or Poison? In PhD Desertation.

Ogato, G. S., Boon, E. K., \& Subramani, J. (2009). Improving Access to Productive Resources and Agricultural Services through Gender Empowerment: A Case Study of Three Rural Communities in Ambo District, Ethiopia. Journal of Human Ecology, 27(2), 85-100. https://doi.org/10.1080/09709274.2009.11906196

Oljira, A. and F. B. (2016). Review on Performance of Formal Rural Financial Institutions in. 26, $24-36$.

Planel, M. L. and S. (2021). “We Cannot Please Everyone ” : Contentions over Adjustment in EPRDF Ethiopia (1991-2018).

Ramanaiah, M. V., \& Gowri, C. M. (2011). A review of Ethiopian institutions and their role in poverty reduction : A case study of Amhara Credit and Saving Institution ( ACSI ). 5(20), 8117-8124. https://doi.org/10.5897/AJBM11.059

Robert Cull, Asli Demirgüç-Kunt, and J. M. (2006). Financial Performance and Outreach: A Global Analysis of Leading Microbanks. WPS3827, Mix, 1-51.

Salami, A., Kamara, A. B., Abdul, B., \& John, C. (2010). Smallholder Agriculture in East Africa: Trends , Constraints and Opportunities (Issue April).

Sibiko, K. W., Veettil, P. C., \& Qaim, M. (2018). Small farmers' preferences for weather index insurance: Insights from Kenya. Agriculture and Food Security, 7(1), 1-14. https://oi.org/10.1186/s40066-018-0200-6

Tesfay, M. G. (2021). Cogent Food \& Agriculture The impact of participation in rural credit program on adoption of inorganic fertilizer: A panel data evidence from Northern Ethiopia The impact of participation in rural 
credit program on adoption of inorganic fertilizer: A pa. Cogent Food \& Agriculture, 7(1). https://doi.org/10.1080/23311932.2021.1919388

Teshome, T. (2008). Role and potential of "iqqub" in Ethiopia (Issue August). Addis Ababa University, Addis Ababa.

Tizazu, E. (1994). Type of Insurance companies operating in Ethiopia.

Toka, A. S., \& Asha, A. A. (2019). Challenges and contributions of informal finance to the livelihoods of rural households in Gamo Gofa. 11(May), 94-105. https://doi.org/10.5897/JAERD2018.1028

Vanroose, A., \& D'Espallier, B. (2013). Do microfinance institutions accomplish their mission? Evidence from the relationship between traditional financial sector development and microfinance institutions' outreach and performance. Applied Economics, 45(15), 1965-1982. https://doi.org/10.1080/00036846.2011.641932

Wassie, S. B., Kusakari, H., \& Sumimoto, M. (2019). Performance of Microfinance Institutions in Ethiopia : Integrating Financial and Social Metrics. Social Science, 8(117), 1-13.

World Bank. (2008). World Bank. 2007. World Development Report 2008: Agriculture for Development. Washington, DC. (C) World Bank. (Vol. 53, Issue 9).

Zeleke, A. T., \& Endris, A. K. (2019). Household Saving Behavior and Determinants of Savings in Financial Institutions : The Case of Derra District, Oromia Region ,. Research Journal of Finance and Accounting, 10(23), 20-27. https://doi.org/10.7176/RJFA/10-23-03

Zeller, M., \& Sharma, M. (2000). Many borrow, more save, and all insure: Implications for food and micro-finance policy. Food Policy, 25(2), 143-167. https://doi.org/10.1016/S0306-9192(99)00065-2 